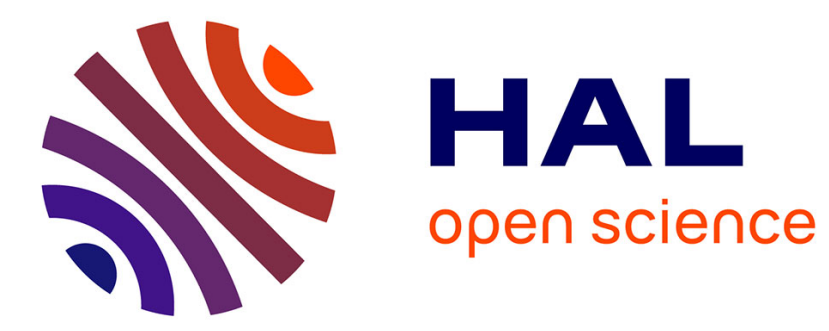

\title{
Predicting subsidence of cohesive and granular soil layers reinforced by geosynthetic
}

Marwan Al Heib, Mouhamad Hassoun, Fabrice Emeriault, Pascal Villard, Abbas Farhat

\section{To cite this version:}

Marwan Al Heib, Mouhamad Hassoun, Fabrice Emeriault, Pascal Villard, Abbas Farhat. Predicting subsidence of cohesive and granular soil layers reinforced by geosynthetic. Environmental Earth Sciences, 2021, 80 (2), 10.1007/s12665-020-09350-3 . hal-03110016

\section{HAL Id: hal-03110016 https://hal.univ-grenoble-alpes.fr/hal-03110016}

Submitted on 7 Jun 2021

HAL is a multi-disciplinary open access archive for the deposit and dissemination of scientific research documents, whether they are published or not. The documents may come from teaching and research institutions in France or abroad, or from public or private research centers.
L'archive ouverte pluridisciplinaire HAL, est destinée au dépôt et à la diffusion de documents scientifiques de niveau recherche, publiés ou non, émanant des établissements d'enseignement et de recherche français ou étrangers, des laboratoires publics ou privés. 


\title{
Predicting subsidence of cohesive and granular soil layers reinforced by geosynthetic
}

\author{
Marwan Al Heib ${ }^{1}$, Mouhamad Hassoun ${ }^{1,2}$, Fabrice Emeriault ${ }^{2}$, Pascal Villard ${ }^{2}$, Abbas Farhat ${ }^{1}$.
}

\author{
${ }^{1}$ Ineris - Artem - Nancy, 54042, France \\ ${ }^{2}$ Univ. Grenoble Alpes, CNRS, Grenoble INP, 3SR, Grenoble, 38041, France \\ Correspondence to: Marwan Al Heib (marwan.alheib@ineris.fr)
}

\begin{abstract}
Subsidence can result from the collapse of underground cavities. The impact of such subsidence on existing structures and infrastructures is generally dramatic. Geosynthetic reinforcement (GSY) is an attractive mitigation solution that

10 can be used to reduce this impact. This paper focuses on the mitigation solutions over existing cavities mainly on the GSY mitigation method. A large-scale physical model $(1-\mathrm{g})$ is used to study the subsidence mechanisms and to estimate the efficacy of GSY for both cohesive and granular overlying soils. The results show that the presence of GSY reduces the ground movement due to the cavity progress toward surface, even under significant overload (traffic, localised foundation, etc.). The deformation of the GSY and the scenario for ground surface movement (subsidence or sinkhole) depend on both the soil type
\end{abstract}

15 and overload intensity. The experimental results are compared to the analytical solutions proposed in order to design the GSY for cohesive and granular soils. In particular, the influence of the vertical stress distribution acting on the GSY is investigated. Different geometries of stress distribution are proposed for granular soils as a function of the loading mode (self-weight or localised overload). For cohesive soils, the action of the collapsed soil on the GSY sheet is found to be well estimated by considering the effect of a simplified system composed of two well localised punctual forces. The analytical and experimental

20 results obtained are rather similar, proving the relevance of the analytical models in predicting the behaviour of reinforced soil layers taking into consideration the real stress distribution deduced from the experimental results.

\section{Introduction and objectives}

The collapse of natural and anthropic cavities is a worldwide geohazard challenge (Gutiérrez et al. 2014, Hutchinson et al. 2002). Karst terrain and natural cavities can be found throughout the world (Closson et al. 2005, Waltham et al. 2005, Figure

25 1.a). Florida is one of the most affected regions in the world for sinkholes (Brinkmann et al. 2008, Galve et al. 2011) with approximately 81 percent of the terrain containing karst. In France, the national geology services estimate the number of cavities as large as 500 000. Some regions such as "Haute Normandie", "Picardie" and "Île-de-France" in France are particularly concerned by geohazard issues (Figure 1.b). The density of cavities on the Normandy plateau is around 14/km². More than 3000 ha are affected by abandoned mines. In the iron ore basin in "Lorraine" (North-East France), there are more

30 than 2000 hectares of mined ground underlying urbanized areas.

The stability of the cavities evolves over time and degrades as a function of intrinsic and/or external conditions: properties of the rock, water infiltration and circulation, overload, traffic, etc. A local instability phenomenon occurs first within the cavity (roof, wall sides, pillars, Figure $2 \mathrm{a}$ and $\mathrm{b}$ ) and then progresses to reach the ground surface (Figure 2.c). Underground cavities can collapse gradually or abruptly depending on the nature of the underlying soil and the geometry of the void. Subsidence, 
sinkholes and crown holes are not recent phenomena, but the latest field observations have shown that their occurrence is more noticed as the world becomes increasingly urbanized (Crilly 2001, Thierry et al. 2009, Gombert et al. 2014). The term sinkhole is most commonly used in the international literature when addressing engineering and environmental issues (Gutiérrez et al. 2008). The soil/rock layers over a shallow unstable cavity usually stays intact until the underground void simply gets too big.

5 If there is not enough support for the soil cover, then a sudden collapse of the ground surface can occur. Cavity collapses are a serious geohazard to structures and infrastructures since they remain undetected until their sudden occurrence on the surface. The damages induced by subsidence or sinkhole can be extremely serious in terms of both safety and economics when they affect critical infrastructures (highways, railways, see Weary 2015) (Figure 3). Table 1 gives an initial scale of risk and damage as a function of the diameter of the sinkhole (hazard).

10 Predicting cavity collapse is a very difficult issue comparative to the situation for other natural hazards (earthquakes, landslide, etc.). The choice and the design of mitigation methods are generally based on the knowledge of the site and on the expected failure mechanism, i.e. the characteristics of the cavities and associated ground movement scenario: subsidence or sinkhole. The depth and geometry of the cavities are the main determinant parameters for defining the sensitivity of a territory. Georgical studies and mining activities can be used to define the hazard zones (Ozdemir 2015). It is also important to gather information

15 on the size and frequency of the past sinkhole events and subsidence phenomena. Identifying sensitive areas that may be affected by subsidence is usually a difficult task (Gutiérrez et al. 2008). Databases and maps of past subsidence events can be obtained from archives (technical and audio-visual) and in situ observations. More detailed information can be collected from geological and geophysical investigation, speleological explorations, trenching, dating techniques and boreholes.

The risk assessment methods and mitigation solutions for protecting urban areas, structures and infrastructures from ground

20 movements are continuously improving. The objectives of the present work are to: 1) summarize and discuss the principal mitigation and remediation methods for ground movements 2) study the efficacy of GSY as a mitigation method for different load scenarios 3) better understand the difference in behaviour between granular and cohesive soil layers reinforced by a GSY 4) compare the analytical models proposed for granular and cohesive soils with experimental results and 5) validate and improve the analytical design methods. The experimental works were carried out using a 1-g large scale physical model.

\section{Mitigation and remediation methods for ground movements}

The safest risk management strategy for ground movements is to either eliminate the hazard (i.e. total backfilling of the cavities) or prohibit public access to the areas susceptible to subsidence. When subsidence occurs in urban areas or areas with infrastructures, the risk can be mitigated by reducing the soil occupation and limiting the severity of the processes (hazard) and the vulnerability of elements at risk, or both. In order to select the right risk management measure, the history and the

30 characteristics of the past sinkholes must be characterized and the areas where future sinkholes are likely to occur must be delineated (Gutiérrez et al. 2008). The optimal risk management method is the one which strikes a balance between an acceptable risk level and the mitigation-repair cost estimated through a cost-benefit study (Galve et al. 2012). The selected risk management method should take into consideration: the type of expected ground movement (subsidence or sinkhole, slow or brutal failure), tolerable damage related to structure and infrastructure categories. The loss of life should not be tolerated.

35 Different types of risk management strategies can be applied to protect structures from sinkhole development (Gongyu and Wanfang 1999, Thornbush 2017). Table 2 summarizes the main risk management methods. Before selecting the management strategy that is most appropriate to the local context and the risk assessment result, the following points should be considered: 
- type of land use and activities;

- hydrogeologic and drainage conditions;

- cavity and overburden characteristics.

The best remediation for completely removing the hazard appears to be filling cavities by grouting. This is suitable in the case

5 of potential sudden collapses (Sowers 1996). However, cavity filling is a costly operation that may block most of the flow paths, concentrating underground flow along particular conduits, thus favouring the dissolution of evaporite rocks (Cooper and Calow 1998). Partial filling can be used to reduce the cost, the hazard level and the disastrous consequences on the soil surface (Al Heib et al. 2010). Positioning special foundations such as piles, micro-piles and rigid inclusions is a common means of transferring the structural load to the soil layers or rigid bedrocks, respectively (Reuter and Stoyan 1993; Cooper and

10 Calow 1998; Waltham et al. 2005) and sinkhole-resistant bridge techniques can be used to improve the strength of the building over a sinkhole (Cooper and Saunders 2002). Parks, linear infrastructures, roads and railways can be reinforced by incorporating GSY over the substratum or within embankments. GSY can prevent local collapse, reduce the consequences and act as a warning system that informs a sinkhole is occurring before it becomes a catastrophic event (Cooper and Saunders 2002, Poorooshasb 2002, Delmas et al. 2015, Abbas and Chungsik, 2017). In addition to the risk prevention and mitigation

15 techniques, vulnerable structures and infrastructures may also be monitored in order to reduce the financial losses and harm to people (Gutiérrez et al., 2008).

\section{Soil reinforcement using GSY over cavities}

GSY is one of the active mitigation techniques used to improve safety and security as underground cavities evolve (Abdelouhab et al., 2018, Delmas and Gourc, 2017). It is now 35 years since GSY appeared in civil engineering works. It was initially used 20 as a needled carpet underlay, and then offered opportunities in fields as varied as the footwear and the automotive industry. Geotextiles were used for the first time in 1969 under embankments built on soft ground in France and UK. The main role of GSY is to prevent the collapse of the soil and limits subsidence at the ground surface. It presents a very attractive solution regarding the cost-benefit balance. Nowadays, improvements in the tensile strength of GSY make it is possible to prevent the consequences of the collapse of cavities with diameters close to $5 \mathrm{~m}$. This diameter corresponds to about $80 \%$ of sinkholes

25 observed (Sartain et al., 2011, Ineris 2001). The ability of GSY to protect the surface from collapsing underground cavities is related to the overlying overload and the thickness of the soil layer over the cavity.

The design of GSY over cavities is still subject to debate due to the complexity of the soil-GSY interaction, the lack of knowledge on load transfer mechanisms and the amount of load transferred to the GSY and, for cohesive soils, the absence of validation of the analytical models. The main aim of the scientific and operational research is to improve the analytical models 30 using indoor tests.

\subsection{Design methods for GSY reinforcement}

The design methods for GSY reinforcement are continually being improved in order to consider in a more physical and accurate manner, the collapse mechanisms of the cavity, the loading modes of the GSY, the load transfer mechanisms and the extent of the surface subsidence due to the collapse of the cavity in the case of reinforced soil (Figure 4). Although the mechanical

35 behaviour of the GSY is currently well understood, the mode of collapse and the action of the collapsed soil on the GSY layer 
remains one of the major preoccupations for granular soils, but especially for cohesive soils. The classical design procedure to be followed to determine the appropriate GSY mechanical properties includes determining:

a) the maximum surface settlement appropriate to the structures and infrastructures concerned;

b) the most likely cavity diameter D at the level of the GSY;

5 c) the maximum allowable strain in the reinforcement such that the criterion in a) is satisfied;

d) the total load acting on the GSY layer;

e) the interactions at the GSY - soil interfaces in the anchorage area;

f) the required tensile stiffness and the maximum tensile strength of the reinforcement;

g) the anchorage length.

10

The literature proposes various different design methods, the majority of which consider the soil to be granular soil. They are considered as relatively pertinent methods to estimate the surface subsidence and to enable the GSY reinforcement to be designed (Giroud et al. 1995, British Standard BS 8006 (2010, Villard and Briançon 2008; Hassoun et al. 2018; Feng et al. 2017; Pham et al. 2018). Giroud et al. (1995) first suggested using of an equilibrium method based on the Terzaghi (1943)

15 approach to estimate the amount of vertical load acting on the GSY. The RAFAEL project (Gourc and Villard, 2000, Blivet et al. 2000) was based on full-scale experiments followed by a numerical study to allow a better understanding of the different mechanisms involved. Similar works were also developed in UK and Germany (Pooroososhasb 2002, Viana et al. 2008, Shukla and Sivakugan 2009, BS8006-2010, Potts and Zdravkovic 2008, EBGEO-2011). Van Eekelen et al (2013) developed a limitstate equilibrium model to represent the arching effect over voids. The German Groebers project, which was similar to the

20 RAFAEL work was carried out to design overbridges for railways over abandoned mine cavities (Ast et al. 2001). The ROSES project (EU Framework IV) studied subsidence mechanisms due to evaporite dissolution and devised management technique (Lamont-Black et al. 2001). Jones and Cooper (2005) covered the design strategy for construction over evaporite sinkholes associated with the ROSES project. Schwerdt et al. (2004) carried out in situ experiments to study the behaviour of GSY over a cavity in the case of granular soil. Briançon and Villard (2008) and Feng et al. (2017) developed an analytical method for

25 GSY design for granular soil embankments subjected to sinkholes taking into account the interaction of the GSY and the granular soil in the anchorage areas. Abbas and Chungsik (2017) described the results of laboratory model tests carried out with emphasis on the effects of GSY reinforcement and they observed the behaviour of ground over sinkholes. The domain of validity of these methods is restricted to the case of granular soil.

Only recently have cases of cohesive natural or treated soil been considered. Based on full-scale experimental tests, Huckert

30 et al. $(2015,2016)$ carried out in situ experimental tests to study the behaviour of GSY under cohesive soil embankments and proposed an analytical design method (Huckert et al. 2015) specifically for cohesive soil. Feng et al (2019) and Wu et al (2019) carried out laboratory tests with reinforced sand over sand-clay soils to study the effect of the boundary conditions and the role of consolidation in reducing the settlement. An analysis of the state of the art showed a lack of validation of the analytical models used for granular and cohesive soils. This paper describes an experimental study using a 1-g large scale physical model

35 to validate and improve the analytical design methods.

The analytical design methods used for granular and cohesive materials take into account the flexural behaviour of the GSY above the cavity, the friction between soil and GSY in the anchorage areas, the increase of tensile force in the GSY by friction at the edge of the cavity and the stretching and sliding of the GSY sheet in the anchorage areas. Depending on the nature of the soil embankment and the type of loading (self-weight or overloading), specific geometries of the load distribution acting 
on the GSY above the cavity are proposed. The main equation for GSY behaviour (equation 1) is established by equalizing the increase in length of GSY sheet $(\Delta \mathrm{L})$ (Villard and Briançon 2008) due to its new geometry and the increase due to:

- its stretching (taking into account the strain $\varepsilon(\mathrm{x})$ of all elementary sections of the sheet $\delta \mathrm{s}$ in the part of the GSY above the cavity),

5 - its sliding (function of $\mathrm{U}_{\mathrm{A}}$ )

- and the initial elongation (increase of the GSY length) of the part of the GSY above the cavity resulting from its installation without careful prestressing (function of $\varepsilon_{\mathrm{w}}$ ).

$\mathrm{U}_{\mathrm{A}}$ is the relative displacement between soil and reinforcement at the edge of the cavity $\left(\mathrm{U}_{\mathrm{A}}>0\right)$ which is due to the stretching and the sliding of the GSY sheet in the anchorage areas. $\varepsilon_{\mathrm{w}}$ is the initial strain is due to the initial ripples of the sheet that must

10 be reached to mobilize tensile forces in the sheet. $\mathrm{z}(\mathrm{x})$ is the vertical displacement of the GSY and $\mathrm{J}$ its tensile stiffness. $\mathrm{T}_{\mathrm{H}}$ is the horizontal component of the tensile force $\mathrm{T}(\mathrm{x})$ in the part of the GSY above the cavity. $\mathrm{T}_{\mathrm{H}}$ is constant along the GSY, as can be demonstrated by studying the force equilibrium in the $\mathrm{x}$ direction. The system of equations (1 to 3 ) for which $\mathrm{T}_{\mathrm{H}}$ is the unknown variable to be determined can be solved by an iterative process.

$15 \Delta L=\int_{x=0}^{x=D / 2} \partial s-\frac{D}{2}=\int_{x=0}^{x=D / 2} \varepsilon(x) . \partial s+U_{A}+D \varepsilon_{w}$

with:

$$
\begin{aligned}
& \int_{x=0}^{x=D / 2} \partial s=\int_{x=0}^{x=D / 2}\left(\sqrt{1+\left(\frac{d z}{d x}\right)^{2}} d x\right. \\
& \int_{x=0}^{x=D / 2} \varepsilon(x) . \partial s=\int_{x=0}^{x=D / 2} \frac{T_{H}}{J}\left[1+\left(\frac{d z}{d x}\right)^{2}\right] d x
\end{aligned}
$$

20 For granular soils, $\mathrm{U}_{\mathrm{A}}$ can be calculated by equations 4 to 6 considering the friction on the upper and lower interfaces between soil and GSY (Villard and Briançon 2008). q is the vertical uniform load acting on the GSY sheet in the anchorage areas, $\delta_{\mathrm{s}}$ and $\delta_{\mathrm{i}}$ are the friction angles of the upper and lower interfaces respectively, and $\mathrm{U}_{0}$ is the value of the relative displacement between soil and GSY required to fully mobilize the interface friction. $\mathrm{T}_{\mathrm{A}}$ is the tensile force that is mobilized in the GSY at the edges of the anchorage areas and $\tau_{0}, \mathrm{r}, \alpha$ and $\beta$ are constants defined in the List of notations.

25

$$
\begin{array}{lll}
U_{A}=T_{A} / J r & \text { if } & U_{A} \leq U_{0} \\
U_{A}=U_{0}+\left\lfloor T_{A}^{2}-\left(U_{0} J r\right)^{2}\right] /\left(2 J \tau_{0}\right) & \text { if } & U_{A}>U_{0} \\
T_{A}=T_{H} \sqrt{1+\beta^{2}} /\left[e^{\alpha A \tan \beta \tan \delta_{i}}\right] & &
\end{array}
$$

30 In the case of granular soils, the average stress acting above the cavity on the GSY sheet ( $\left.\sigma_{\mathrm{vg}}\right)$ is usually defined using Terzaghi's formulation (equation 7; Terzaghi 1943). $\mathrm{K}$ is the ratio between horizontal and vertical stresses, $\gamma$ the soil unit weight, $\varnothing$ its internal friction angle, $\mathrm{H}$ the embankment thickness, $\mathrm{D}$ the cavity diameter and $\mathrm{p}$ the uniform overload applied 
on the soil surface. The choice of the $\mathrm{K}$ value is under discussion at the present time. Following 2D laboratory experiments, Chevalier et al. (2012) proposed K values equal to 0.55 and 1.2 for coarse sand and gravel respectively. Considering that the ratio $\mathrm{H} / \mathrm{D}$ is small in the experiments performed in section 3.2, the choice of $\mathrm{K}$ is not of major importance, and so $\mathrm{K}$ is assumed in this paper to be the active earth pressure coefficient $\left(\mathrm{K}_{\mathrm{a}}\right)$.

5

$\sigma_{v g}=\frac{D \gamma}{4 K \tan \phi}\left(1-e^{-K \tan \phi \frac{4 H}{D}}\right)+p e^{-K \tan \phi \frac{4 H}{D}}$

Depending on the opening mode of the cavity and the loading type, the geometries of the soil stress distribution acting on the GSY sheet can differ. In the case of the trapdoor problem (similar to the experiments presented in 3.2), the load distribution 10 acting on the GSY sheet (Villard et al. 2016, Hassoun et al. 2018, Chalak et al. 2019) was found to be non-uniform. The observed shape of an inverted triangular distribution leads to greater vertical stresses in the vicinity of the cavity edges. In the case of an overloading by punctual loads on the axis of the cavity, one can expect an increase in the vertical loading in the central part of the sheet. To compare the experimental and analytical results, different geometries of vertical loads were tested (uniform, inverted triangular, parabolic). The horizontal and vertical forces equilibrium applied to any parts of the sheet leads 15 to the following equations, which can be used for all proposed load distributions (Table 3).

$$
\frac{q(x)}{T_{H}}=\frac{d^{2} z(x)}{d x^{2}} \quad \text { and } \quad T(x)=T_{H} \sqrt{1+\left(\frac{d z(x)}{d x}\right)^{2}}
$$

For cohesive soils, we assume, as proposed by Huckert et al. (2015), that the actions of the collapsed soil blocks that fall down onto the GSY sheet can be represented by two symmetric punctual vertical loads of intensity F distant from 21 (Figure 5).

The equation characterising the behaviour of the GSY (derived from equation 1) can be written as follows (Huckert et al. 20 2015):

$$
\begin{aligned}
& \int_{x=0}^{x=L} \partial s-\frac{D}{2}=l+d-\frac{D}{2}=\left(\sqrt{1+\left(\frac{F}{T_{H}}\right)^{2}}-1\right)\left(\frac{D}{2}-l\right) \\
& \int_{x=0}^{x=L} \varepsilon(x) . \partial s=\frac{T_{H}}{J}\left[\left(1+\left(\frac{F}{T_{H}}\right)^{2}\right)\left(\frac{D}{2}-l\right)+l\right] \\
& \left(\sqrt{\left.1+\left(\frac{F}{T_{H}}\right)^{2}-1\right)\left(\frac{D}{2}-l\right)=\frac{T_{H}}{J}\left[\left(1+\left(\frac{F}{T_{H}}\right)^{2}\right)\left(\frac{D}{2}-l\right)+l\right]+U_{A}+D \varepsilon_{w} \text { with } U_{A}>0}\right. \\
& f_{\max }=\frac{F}{T_{H}}\left(\frac{D}{2}-l\right) \\
& 25 T_{\max }=T_{H} \sqrt{1+\left(\frac{F}{T_{H}}\right)^{2}}
\end{aligned}
$$




\subsection{Physical model (1-g) and description of tests}

Physical modelling refers to experiments designed to reproduce physics and engineering issues. The model considered in this paper is used in a 1-g environment (earth gravity) as opposed to a n-g model (which requires a centrifuge facility). The model should respect similarity laws (Garnier et al. 2007, Feng et al, Wu et al. 2019). The objective of the physical model is to

5 simulate the surface ground movements due to mining and underground cavities. Ineris has developed a physical model (1-g) to study the risks associated with the collapse of underground cavities (Figure 6, Al Heib et al. 2013, Al Heib et al. 2020). The model consists of a tank designed to receive up to $6 \mathrm{~m}^{3}$ of soil: $3 \mathrm{~m}$ long, $2 \mathrm{~m}$ wide and $1 \mathrm{~m}$ high (Figure 6.a). The test platform is equipped with 15 jacks to reproduce the cavity development and the resulting ground movements, each associated with a square trapdoor $0.25 \mathrm{~m}$ by $0.25 \mathrm{~m}$. Thus, the physical model makes it possible to reproduce the formation of a maximum cavity

10 size of $1.25 \mathrm{~m}$ by $0.75 \mathrm{~m}$. For the GSY tests, the model is equipped with: i) 7 radar sensors (Figure 6.b, RAdio Detection And Ranging) to detect the object position and measure the vertical displacements of the GSY, ii) 7 pressure sensors (Figure 6.b) to estimate the vertical stress within the soil around the cavity and iii) two cameras to detect the 3D movements of the surface (Figure 6.c). Table 4 presents the principal characteristics and degree of precision of the main sensors. We should note the high theoretical precision of the measurements covering the objective of the study. Figure 7 presents the location of the radars

15 and pressure cells. Two types of soils were used:

- Fontainebleau sand (SF), with $\mathrm{D}_{50}=200 \mu \mathrm{m}$, a dry granular soil commonly used in laboratory tests (Popa et al. 2003)

- and a sand-clay mixture (SK), commonly used as cohesive soil in laboratory experiments (Boussaid 2005): it consists of 70\% dry Fontainebleau sand $+30 \%$ dry kaolin, brought to a water content of $8 \%$ for all the experiments. This type of material makes it possible to reproduce in small-scale experiments the behaviour of natural cohesive soils such as those used in classical

20 geotechnical applications.

Laboratory tests were carried out to obtain the mechanical parameters of the soils (triaxial and shear tests) and the GSY. The average values of the mechanical parameters were used for the analytical calculation (Hassoun, 2019). The sand was characterized by a density of $15.4 \mathrm{kN} / \mathrm{m}^{3}$ and a friction angle of $35^{\circ}$. The cohesive soil had a dry density of $15.3 \mathrm{kN} / \mathrm{m}^{3}$, a cohesion of $35 \mathrm{kPa}$ and a friction angle of $29^{\circ}$.

25 The GSY was bi-directional, made of polyester (PET), and characterized by a failure tensile strength of $11.9 \mathrm{kN} / \mathrm{m}$, a failure strain of $12 \%$ and an initial tensile stiffness corresponding to $2 \%$ of strain of approximately $170 \mathrm{kN} / \mathrm{m}$. The $1.7 \mathrm{~m} \times 1 \mathrm{~m}$ GSY sheet was fixed only in the longitudinal direction at the borders of the tank, so as to achieve the assumption of unidirectional reinforcement.

Four tests, two repetitions for each type of soil, were carried out to reproduce the formation of a cavity at the base of granular

30 (SF) or cohesive (SK) soil layers, with a constant soil thickness $\mathrm{H}=0.125 \mathrm{~m}$, reinforced by the GSY. The cavity had a square section $(D=0.50 \mathrm{~m})$. The ratio between the thickness of the soil layer and the width of the cavity was $H / D=0.25$, which reflects the key use of GSY over cavities. The test procedure was:

- installing and compacting the soil to obtain the target density,

- lowering the jacks to simulate the progressive cavity formation,

35 - progressive loading on the soil surface (until failure is obtained in the case of the cohesive soil),

- and final unloading.

A result analysis was performed at each step: initial, after full cavity opening, during loading and unloading. The soil was first submitted to its own weight then loaded vertically by the way of a rigid slab $(0.15 \mathrm{~m} * 0.15 \mathrm{~m})$ applied at soil surface on the axis of the cavity. During the cavity opening, the velocity of the jacks was constant $(0.03 \mathrm{~mm} / \mathrm{sec})$ and automatically controlled. All 
the data were recorded by a data logger connected to the computer. During the tests with cohesive soil, a simple measurement system was installed in order to assess a posteriori the displacements induced by soil subsidence on the displacement of the GSY at the edges of the cavity (the average of the 4 measured values is presented here).

\section{$4 \quad$ Results and discussion}

5 The behaviour of the soil and GSY was described and analysed for the 4 different tests through direct observation, image correlation and measurement devices.

\subsection{Granular soil - Fontainebleau sand (SF)}

In the absence of the GSY, the cavity opening created a complete void at the surface as expected. The results obtained by $\mathrm{Al}$ Heib et al. (2013) showed that in this case, the amplitude of the subsidence on the surface increases with the cavity depth for

10 sandy soil. The soil expands when extracted from a site or when failing, the bulking factor expresses the corresponding increase in the soil volume, compared to the initial volume. The bulking factor $\left(C_{e}\right)$ of the granular material used is equal to 1.06 . The presence of the GSY limits the soil collapse and induces subsidence with a maximum value in the centre of the cavity equal to $27.8 \mathrm{~mm}$ for test SF1 and 23.9 for test SF2 (Figure 8 and Figure 9).

Regarding the first step of the test on the reinforced soil layer, corresponding to the creation of the cavity, the vertical

15 displacement (deflexion) of the GSY is rather flat, mainly in the central part above the cavity (Figure 9). This may be explained by the fact that the load acting on the GSY is not uniform as discussed by Huckert et al. (2016) and Feng et al. (2017). As mentioned, the maximal vertical displacement at the soil surface (S) is equal to $27.6 \mathrm{~mm}$ and $22.32 \mathrm{~mm}$ for SF1 and SF2 respectively but the size of the zone affected by the surface settlement is slightly larger than the area of the cavity. The maximum deflexion of the GSY for the two experiments (SF1 and SF2) is respectively $43.2 \mathrm{~mm}$ and $39.8 \mathrm{~mm}$, which

20 corresponds to a bulking factor $C_{e}$ of 1.05 . The value of the bulking factor with and without GSY is expected to remain relatively constant.

Figure 10 shows the location of the stress sensors and presents the measurements of the vertical stresses before (initial) and after the formation of the cavity (final). The initial stress measured (Figure 10.a) was close to the expected theoretical lithostatic pressure $\gamma H$ (with a difference limited to $+/-20 \%$ ). Despite the high precision of the stress cells, the results should be

25 considered as a qualitative indicator rather than a quantitative one. Measuring stress in sand is very difficult because of the arching effect and the behaviour of the sand (Hassoun et al. 2018). The final stresses (Figure 10.b) increased by $60-80 \%$ of $\gamma \mathrm{H}$ after the formation of the cavity for cells close to its edges (C7 and C13) and by about 20\% for those far from the cavity (C2 and $\mathrm{C} 3)$.

Increases in vertical stress, after each overloading phase, were also observed on all stress sensors (Figure 11). The cells close

30 to the edges of the cavity were the most affected by the overload: C7, C8 and C13. This increase in stress in the vicinity of the cavity indicates a persistent load transfer mechanism within the granular layer. Small variations were observed for the cells further away from the cavity (C2, C3 and C4).

The vertical displacements of the GSY were calculated using the analytical models presented in Table 3 and developed in 2D by Briançon and Villard (2008) for granular soil. The two interface friction angles (GSY/soil and GSY/wood plate) in the 35 anchorage zones were estimated at $30^{\circ}$ and $22^{\circ}$ respectively. The value of $\mathrm{U}_{0}$, corresponding to the relative displacement 
between soil and GSY required to fully mobilize the interface friction, was assumed to be $1 \mathrm{~mm}$. As already mentioned, the sandy soil (SF) characteristics were $\gamma=15.4 \mathrm{kN} / \mathrm{m}^{3}$ and $\phi=35^{\circ}$.

The load transfer hypothesis proposed by Terzaghi for circular cavities (Equation. 7, 1943) leads to a theoretical value of $1.75 \mathrm{kN} / \mathrm{m}^{2}$ for the uniformly distributed load $\sigma_{\mathrm{vg}}$ acting on the GSY. This amount of load is assumed to be distributed on the

5 GSY sheet as an uniform load distribution (Figure 12.a), as a 3D inverted triangular shape (Figure 12.b) or as a paraboloid of revolution - i.e. the intersection between the external surface of the paraboloid and a vertical plane passing through the axis of the cavity is always a parabola(Figure 12.c). The 2D analytical method was applied on the thin central strip of the GSY sheet, which leads to the maximal vertical displacements (Figure 13). The maximum value of the load that needs to be considered (q1) was obtained by considering that the total amounts of the vertical load acting on the GSY sheet to be similar for the three 10 cases. Based on this assumption, the maximum overload value for the uniform distribution is therefore $\mathrm{q} 1=\sigma_{\mathrm{vg}}$, for the parabolic distribution it is $q 1=2 \sigma_{\mathrm{vg}}$, and for the inverted triangular distribution $\mathrm{q} 1=3 / 2 \sigma_{\mathrm{vg}}$. The analytical results obtained for the three proposed load distributions were compared to the experimental results considering that $\varepsilon_{\mathrm{w}}=0$ (Figure 14). As can be seen, the analytical shape of the curve obtained with the assumption of an inverted triangular load distribution is rather similar to the experimental flattening shape obtained during the experiment, although the maximum vertical displacement

15 obtained analytically is smaller. This can be explained by the fact that the GSY sheet was not perfectly plane when it was installed (and therefore that a certain elongation could be observed before a tensile force developed in the GSY). The curves obtained when considering uniform and parabolic shapes did not match the shape of the experimental curve, therefore these load distribution shapes are not adapted for the cases of cavity opening. Moreover, the analytical maximum vertical displacement value for parabolic shape distribution is also greater than the experimental one. As it can be seen in Table 5, the

20 analytical model provides relevant information about the sliding and the stretching of the GSY sheet in the anchorage areas as well as the maximal tensile force.

After the opening of the cavity, the soil surface was overloaded in the centre of the cavity on a $0.15 \mathrm{~m}$ wide square surface. The overload was applied progressively in three phases: 150, 350 and 550 N. Figure 15 shows the vertical displacements of the GSY for the two tests (SF1 and SF2). Applying a localized overload on the axis of the cavity increased the GSY deflexion 25 mainly in the central part of the cavity. The unloading phase resulted in a heave of the GSY. The GSY deflexion obtained at the end of the unloading remained nevertheless greater than the value before loading, due to the sliding of the GSY in the anchorage areas and the presence of the soil layer that collapsed on the GSY and whose behaviour is not reversible (Figure $15)$.

To compare the analytical deformation of the GSY to the experimental one, three geometries of stress distribution on the GSY 30 were considered: uniform, inverted triangular and parabolic. As previously, the total amounts of the vertical stresses $\left(\sigma_{\mathrm{vg}}\right)$ acting on the GSY (Table 6) were calculated using the Terzaghi approach (Equation 7, 1943). The localised overloads (p) were dispatched considering the whole surface of the cavity $(0.5 \mathrm{~m} \times 0.5 \mathrm{~m})$. The main results expressed as maximum vertical displacement $\left(f_{\max }\right)$, maximum tensile force $\left(T_{\max }\right)$ and maximum horizontal displacement $\left(\mathrm{U}_{\mathrm{A}}\right)$ of the GSY in the vicinity of the edges of the cavity are presented in Table 6 and summarized in Figure 16. As can be seen in Figure 16, it is necessary to

35 take into account various load distribution shapes to reproduce all the experimental results: parabolic shapes for the greater overloads, uniform distribution for low overloads and inverted triangular shapes when considering the self-weight loading of the granular layer. Nevertheless, the correspondence of the analytical results with the experimental ones is not completely satisfactory. Therefore, it has been proposed to consider increasing the length of the sheet $\left(\mathrm{D} \varepsilon_{\mathrm{w}}\right)$ in the analytical approach, due to the initial waves resulting from the installation of the GSY without careful prestressing. To match the experimental 
results, the best value of $\mathrm{D} \varepsilon_{\mathrm{w}}$ has to be equal to $4 \mathrm{~mm}$ (corresponding to $\varepsilon_{\mathrm{w}}=0.8 \%$ ) which is a realistic value considering the experimental procedure for installation. Inverted triangular load distribution was considered under self-weight, uniform load distribution for an overload of $150 \mathrm{~N}$, and parabolic load distribution for overloads of $350 \mathrm{~N}$ and $450 \mathrm{~N}$ respectively. In the case of unloading, a uniform load distribution was considered (no arching effect and no overloading) assuming that the

5 horizontal sliding displacement of the sheet in the anchorage area is non-reversible so that the displacement $\mathrm{U}_{\mathrm{A}}$ remains equal to the value of $\mathrm{U}_{\mathrm{A}}$ obtained after the last step of loading. Table 6 summarizes the main results at each step of the loading and for the chosen load distributions. A comparison between the experimental and analytical results of the GSY vertical displacements profiles is presented in Figure 17.

As it can be seen in Figure 17, the results of the initial waves $\left(\mathrm{D} \varepsilon_{\mathrm{w}}=4 \mathrm{~mm}\right)$ match the experimental results very well for each

10 step of the loading, which validates the nation of introducing initial waves in the analytical approach. The good match between the curves presented in Figure 17 also indicates that it is necessary to consider different types of load distributions to reproduce the experimental results. Therefore, loading the soil surface modifies the geometry of the load distribution on the GSY, from an initially inversed triangular distribution to a distribution where the maximum value is located in the centre of the cavity. The unloading behaviour is also well described when considering the non-reversible displacement of the sheet in the anchorage 15 areas.

The necessity to take into account different shapes of stress distribution, depending on loading process or cavity opening mode, was mentioned in the literature by various authors (Villard et al, 2016; Chalak et al, 2019; da Silva Burke, 2020). As an example, the experimental results presented in this paper are in good accordance with the results presented by Villard and Briançon (2008) concerning the influence of the embankment overloading on the vertical stress distribution acting on the GSY.

20 It changes progressively from inverted triangular (under the soil self-weight) to parabolic (for large overloads). The experimental observations should be considered for designing a GSY with large overload case studies. The new results confirmed that the procedure can be considered as a valid method for granular soil layer.

\subsection{Cohesive soil: sand-kaolin}

25 Two tests were carried out with cohesive soil (SK1 and SK2, Al Heib et al. 2020). Under the self-weight of the soil, the cohesive soil layers bridge the cavity area and behave as a flexural slab which limits the vertical displacement to values smaller than $2 \mathrm{~mm}$. The maximal vertical displacement of the GSY on the axis of the cavity is $7 \mathrm{~mm}$ due to its own weight. The stresses measured before the creation of the cavity were on average $20 \%$ higher than the expected value of $\gamma \mathrm{H}$. The stresses increased after the opening of the cavity on the sensors close to the cavity C7, C8 and C13, C10 (Figure 18). The sensors furthest from

30 the cavity (C2, C3 and $\mathrm{C} 4)$ recorded only a small stress increase. The cohesive soil layer behaves as a continuous slab due to the strength in traction of the sand-kaolin mixture.

Figure 19 presents a comparison of stress measurements between granular and cohesive soil is presented in. The loads of the C2, C3 and C4 cells, the furthest away from the cavity, were greater in the case of the granular soil the cohesive soil, for which very small increases in stress were recorded. As a result, in the case of granular soils, the transferred loads were less intense

35 and more diffuse, but they were more intense and localized on the edges of the cavity due to the beam-like behaviour of the cohesive soil layer. 
In order to create a sinkhole and mobilise the GSY, a progressive load was applied on the soil surface on the axis of the cavity, $0.15^{*} 0.15 \mathrm{~m}^{2}$. A sudden collapse occurred for a load of $550 \mathrm{~N}$ in both cases SK1 and SK2. The collapse of the soil layers resulted in a sinkhole restricted to the loading surface (Figure 20.a). The volume of collapsed soil was approximately a truncated pyramid of height $\mathrm{H}$ with a base equal to the size of the cavity $(0.5 \mathrm{~m} \times 0.5 \mathrm{~cm}$, Figure $20 . \mathrm{b})$. This experimental result 5 is similar to the results of Huckert et al. 's (2015) experiments and in situ observations.

The collapse of the soil layer induced a vertical displacement of the GSY of 54.6 and 58.6mm for the two tests SK1 and SK2 (Figure 22). The average horizontal slippage of the GSY at the edges of the cavity for SK1 and SK2 was around 1.375mm. A comparison of the GSY deformations between the experiments with Fontainebleau sand (SF) and the cohesive soil (SK) obtained under the same loading conditions ( $550 \mathrm{~N}$ ), shows (Figure 23) that the deformation of the GSY for cohesive soil was

$1030 \%$ less than the deformation obtained in sandy soil. The shape of the deformation was flat in the case of the cohesive soil. This flat shape was a consequence of the breakage in blocks acting in a specific way on the GSY. In the case of the sandy soil layer, there was a gradual evolution of the GSY deflexion, whereas a sudden soil movement was obtained at between $350 \mathrm{~N}$ and $550 \mathrm{~N}$. In addition, with the cohesive soil, the deformations of the GSY in the central part of the cavity were always smaller than those obtained with the sand, even after unloading.

15 We used the model developed by Huckert et al. (2016) to compare the analytical deformation of the GSY to the experimental one. The collapse mechanism obtained in Figure 20, which can explain the deformed shape of the GSY is similar to the one proposed by Huckert et al. (2016), who assimilated the action of the collapsed blocks to punctual loads. Based on the experimental observations, two assumptions are proposed for the geometry (and therefore weight) of the blocks acting on the GSY (Figure 21). In the first case (hereafter denoted Analytic 1), only the block of soil 1 directly located below the loading 20 plate is considered. In the second case (Analytic 2), the additional side blocks 2 are considered in the assessment of the punctual forces F. These cases can be viewed respectively as the lower and upper limits of the forces F. Figure 21 also recalls the assumption that only a thin strip of GSY is considered in the calculating the load and therefore the deflexion (in this particular situation, the strip has a width of $0.15 \mathrm{~m}$ corresponding to the width of the loading plate).

Due to the mode of collapse obtained (blocks falling on the sheet), it is assumed that there are no load transfer mechanisms

25 that act to redirect part of the overload onto the sides of the cavity.

The analytical model was applied for comparison with the experimental results. Due to the lack of information about the frictional behaviour between the cohesive soil and the GSY (cohesion and friction angle), the analytical value of the horizontal displacements of the GSY $\left(\mathrm{U}_{\mathrm{A}}\right.$ and $\left.-\mathrm{U}_{\mathrm{A}}\right)$ at the left and right edges of the cavity due to slippage was set using the average experimental value $(1.375 \mathrm{~mm}$ ). Table 7 summarizes the input parameter values (analytic 1 and analytic 2), deduced from

30 observations and experimental measurements, for the use of the Huckert et al. model (2016). As presented in Figure 22, the analytical model for cohesive soil matches the experimental results very well in terms of amplitude and shape, as opposed to the parabolic deformation considered in the case of granular soil.

In order to determine the influence of the $\mathrm{U}_{\mathrm{A}}$ value on the results, Figure 22 also reports the predicted deflexion when considering $\mathrm{U}_{\mathrm{A}}=0$ and the lower limit of the load (Analytic 3 - Table 7). Although the maximum displacement is smaller than

35 for $\mathrm{U}_{\mathrm{A}}=1.375 \mathrm{~mm}$, it appears that the difference is small. It can thus be concluded that in the case of a cohesive soil, the main parameter ruling the GSY deflexion is the load intensity, which induces the failure of the soil layer and dictates the extent of the overload area.

The comparison, for cohesive soil, between the experimental results and the suggested approach has shown a good agreement. These results contribute thus to the validation of the model proposed by Huckert et al. (2016). However, no precise procedure 
exists so far for the design in case of cohesive soil. The analytical model for cohesive soil needs additional laboratory and insitu tests to be generalised and to be considered as a base for the definition of a design procedure.

\section{Conclusions}

5

The synthesis of ground movement risk management methods demonstrates that the GSY can offer an attractive mitigation solution for reducing the risk induced by the formation of sinkholes. To be commonly applied in any geotechnical context, this reinforcement technique must be supported by analytical design methods that takes account of the loading modes (effects of the soil self-weight and surface overloading) and the specificities of the natural soils used (granular or cohesive materials).

10 In this study, a 1-g laboratory experimental campaign was carried out to improve the analytical design methods for GSY. New assumptions covering the amount and distribution shape of the vertical stresses acting on the GSY were proposed for two types of soils and different loading modes in order to be able to routinely apply these reinforcement methods in any geotechnical context. For all the considered cases, the comparison of the experimental and analytical results shows that analytical models can reasonably be used to predict the subsidence of reinforced soil layers.

15 For granular soil, the analytical model proposed by Villard and Briançon (2008) accurately reproduces the different stages of the loading process. The results show that the shape of the vertical stress distribution acting on the GSY changes progressively from inverted triangular (under the soil self-weight) to parabolic (for large overloads). The initial ripples of the part of the GSY situated above the cavity should be taken into account to obtain more pertinent results.

For cohesive soil, the analytical model proposed by Huckert et al. (2016) seems well adapted to design the GSY when

20 considering that the load acting on the GSY is punctually applied. For the experiments performed (low thickness of the cohesive soil layer), the proposed load transfer mechanisms were based on feedback from the experimental results. It was shown that the punctual loads acting on the GSY are located vertical to the edges of the loading plate and that the overload applied on the surface is totally transferred to the GSY (no load transfer mechanism in this case). However, extrapolating these results (number of collapsed blocks and intensity of the load transfer) to various cases (different overloading modes, soil layer

25 thicknesses and cavity diameters) remains a challenge.

For all the cases considered, the comparison of the experimental and analytical results shows that the analytical models can reasonably be used to predict the subsidence of reinforced soils after considering the real load distribution based on the feedback from experimental results. If a larger experimental campaign can be performed, one can expect that it can be possible to predict the intensity and shape of the load distribution acting on the GSY for different soil layer thicknesses, cavity widths,

30 soil types and natures and positions of applied overload. An attractive way to obtain such results could be to use numerical tools and undertake a systematic sensitivity analysis.

\section{References}

Al Heib M, Hassoun M, Villard P, Emeriault F, Farhat A (2020) Subsidence prediction of reinforced soil layer by geosynthetic 35 using large-scale 1g physical model, Proc. IAHS, 382, pp 721-726 
Abdelouhab A, Al Heib M, Pinon C (2018) Sécurisation d'un secteur d'une ancienne carrière souterraine par géosynthétique de très haute résistance $(1800 \mathrm{kN} / \mathrm{m})$. Journée Nationales de Géotechnique et de Géologie de l'Ingénieur, Marne -La-Vallée. https://www.ifsttar.fr/collections/ActesInteractifs/AII3/byTopic.html. Accessed 25 November 2020

Abbas Q, Chungsik Y (2017) Effect of Geogrid on Sinkhole Formation induced Ground Collapse Prevention. 19th 5 International Conference on Soil Mechanics and Geotechnical Engineering, Seoul, pp 2465-2468. https://www.issmge.org/uploads/publications/1/45/06-technical-committee-17-tc211-02.pdf. Accessed 8 July 2020

Al Heib M, Didier C, Masrouri F (2010) Improving Short- and Long-term Stability of Underground Gypsum Mine Using Partial and Total Backfill. Rock Mech Rock Eng 43:447-461. https://doi 10.1007/s00603-009-0066-9

Al Heib M, Emeriault F, Caudron M, Nghiem L, Hor B (2013) Large-scale soil-structure physical model (1-g)-assessment of 10 structure damages. International Journal of Physical Modelling in Geotechnics 13:138-152

Ast W, Sobolewski J, Haberland J, (2001) Final design of an overbridging for railways endangered by cavities at Groebers. Landmarks in earth Reinforcement. Proceedings of the international symposium on earth reinforcement. Fukuoka Japan, H. Ochiai et el. eds, Balkema, Vol. 2, pp 191-196

Balland C, Al Heib M, Didier C (2009) Monitoring the long-term stability and sinkhole of shallow underground cavities using 15 micro-seismic technique - gypsum mine (Jura, France) American Geophysical Union, Fall Meeting 2009, abstract id. S23B1759

Blivet JC, Khay M, Villard P, Gourc JP et al (2000) Experiment and design of geosynthetic reinforcement to prevent localised sinkholes. GeoEng2000, International Conference on Geotechnical and Geological Engineering, pp 1-6

Boussaid K (2005) Intermediate soils for physical modeling: application to shallow foundations. Dissertation, Ecole Centrale 20 de Nantes and Université de Nantes (in French)

Briançon L, Villard P (2008) Design of geosynthetic-reinforced platforms spanning localized sinkholes. Geotextiles and Geomembranes 26:416-428

Brinkmann R, Parise M, Dye D (2008) Sinkhole Distribution in a Rapidly Developing Urban Environment: Hillsborough County, Tampa Bay area, Florida. Engineering Geology 99: 169-184. 2008. doi:10.1016/j.enggeo.2007.11.020

25 BS8006 (2010) Standards Publication Code of practice for strengthened/reinforced soils and other fills. ISBN, 940005429, pp $1-21$

Chalak C, Briançon L, Villard P (2019) Coupled numerical and experimental analyses of load transfer mechanisms in granularreinforced platform overlying cavities. Geotextiles and Geomembranes 47:587-597

Chevalier B, Combe G, Villard P (2012) Experimental and Discrete Element Modelling studies of the trapdoor problem: 30 influence of the macro-mechanical frictional parameters. Acta Geotechnica 7:15-39

Closson D, Karaki NA, Klinger Y, Hussein MJ (2005) Subsidence and Sinkhole Hazard Assessment in the Southern Dead Sea Area, Jordan. 2005. Pure and Applied Geophysics162: 221-248. https://doi:10.1007/s00024-004-2598-y

Cooper AH, Calow RC (1998) Avoiding Gypsum Geohazards: Guidance for Planning and Construction. WC/98/5. British Geological Survey, Nottingham, UK. 
http://nora.nerc.ac.uk/id/eprint/14146/1/Cooper_Callow_1998_DIFID_Gypsum_and_planning_WC_98_005_COL.pdf.

Accessed 8 July 2020

Cooper AH, Saunders JM (2002) Road and bridge construction across gypsum karst in England. Engineering Geology 65:217223

5 Crilly M (2001) Analysis of a database of subsidence damage, Structural Survey 19:7-15

Delmas Ph, Gourc JP (2017) Geosynthetics in transport infrastructures, the positive input of old case histories. Marraekech, Morocco GeoAfrica 2017 Conference pp 17-55

da Silva Burke TS, Elshafie MZEB (2020) Geosynthetic-reinforcement soils above voids: observation of soil and geosynthetic deformation mechanisms. Geotextile and Geomembrane. Article in press

10 Delmas P, Villard P, Huckert A (2015) Short and long term design of geosynthetic reinforcement structure over soil subsidence: taking into account safety. 10ème rencontres géosynthétiques - France. pp 1-22. https://www.cfg.asso.fr/sites/default/files/files/cd-rom-2015/RG2015\%20pp\%20013.pdf. Accessed 8 July 2020

EBGEO (2011) Recommendations for design and analysis of earth structures using geosynthetic reinforcements-EBGEO. German Geotechnical Society Berlin. https://onlinelibrary.wiley.com/doi/book/10.1002/9783433600931. Accessed 8 July

152020

Edmonds C (2018) Five decades of Settlement and subsidence. Quarterly Journal of Engineering Geology and Hydrogeology 51(4).

Feng SJ, Ai SG, Chen HX (2017) An analytical method for predicting load acting on geosynthetic overlying voids. Geotextiles and Geomembranes 45:570-579

20 Feng WQ, Li C, Yin JH, Chen J, Liu K (2019) Physical model study on the clay-sand interface without and with geotextile separator. Acta Geotechnica, 14 :2065-2081, 10.1007/s11440-019-00763-4

Galve JP, Remondo J, Gutiérrez F (2011) Improving sinkhole hazard models incorporating magnitude-frequency relationships and nearest neighbor analysis. Geomorphology 134:157-170

Galve JP, Gutiérrez F, Guerrero J, Alonso J, Diego I (2012) Application of risk, cost-benefit and acceptability analyses to 25 identify the most appropriate geosynthetic solution to mitigate sinkhole damage on roads. Engineering Geology 145-146:6577

Giroud JP, Bonaparte R, Beech FF, Gross BA (1995) Design layer - geosynthetic systems overlying voids, Geotextiles and Geomembranes 1:11-50

Gombert P, Orsat J, Mathon D, Alboresha R, Al Heib M, Deck O (2014) Rôle des effondrements karstiques sur les désordres 30 survenus sur les digues de Loire dans le Val d'Orléans (France), Bull Eng Geol Environ, https://doi 10.1007/s10064-014-05948

Gongyu L, Wanfang Z (1999) Sinkholes in karst mining areas in China and some methods of prevention. Engineering Geology 52:45-50 
Gourc JP, Villard P (2000) Reinforcement by membrane effect: Application to embankments on soil liable to subsidence. Proceedings of the 2nd Asian Geosynthetics Conference 1:55-72

Garnier J, Gaudin C, Springman SM, et al (2007). Catalogue of scaling laws and similitude questions in geotechnical centrifuge modelling. International Journal of Physical Modelling in Geotechnics, vol. 3, pp 1-23

5 Gutiérrez F, Cooper AH, Johnson KS (2008) Identification, prediction, and mitigation of sinkhole hazards in evaporite karst areas. Environmental Geology. 53:1007-1022. https://doi: 10.1007/s00254-007-0728-4

Gutiérrez F, Parise M, De Waele J, Ourde H (2014) A Review on Natural and Human-induced Geohazards and Impacts in Karst. Earth Science Reviews 138:61-88

Hassoun M, Villard P, Al Heib M, Emeriault F (2018) Soil reinforcement with geosynthetic for localized subsidence problems:

10 Experimental and analytical analysis. Int. J. of Geomechanics ASCE. 18, 10

Hassoun M (2019) Modélisation physique du renforcement par géosynthétique des remblais granulaires et cohésifs sur cavités. Dissertation, Université Grenoble Alpes (in French)

Hutchinson DJ, Phillips C, Cascante G (2002) Risk Considerations for Crown Pillar Stability Assessment for Mine Closure Planning. Geotechnical and Geological Engineering 20: 41-64. https://doi:10.1023/A:1013852722768

15 Huckert A, Villard P, Briançon L, Auray G (2015) Approche expérimentale du dimensionnement d'une couche de sol traité renforcée par géosynthétique sur cavités potentielles. $10^{\text {ème }}$ Colloque francophone sur les Géosynthétiques, Rencontres Géosynthétiques_France, pp 89-97 (In French)

Huckert A, Briançon L, Villard P, Garcin P (2016) Load transfer mechanisms in geotextile-reinforced embankments overlying voids: Experimental and analytical approaches. Geotextiles and Geomembranes 44:442-456

20 IFSTTAR (2014) Le diagnostic de stabilité des carrières souterraines abandonnées, guide méthodlogique: Collection Environnment, les risques naturels. (In French)

Ineris (2001). Analyse des conséquences de mouvements de terrains sur les structures de surface - base de données de l'Inspection Génerale des Carrières. INERIS-DRS-01-25315/RN02 (In French)

Ineris (2007) Mise en sécurité des cavités souterraines d'origine anthropique: Surveillance - Traitement.

25 https://www.ineris.fr/sites/ineris.fr/files/contribution/Documents/Guide_carrieres.pdf (In French)

Ineris (2019) Post-mining hazard Evaluation and Mapping in France. https://www.ineris.fr/sites/ineris.fr/files/contribution/Documents/Ineris-Guide_Aleas_miniers_VA-Web_C03.pdf

Jones CJFP, Cooper AH (2005). Road construction over voids caused by active gypsum dissolution, with an example from Ripon, North Yorkshire, England. Environmental Geology 48:384-394

30 Kleinhans I, Van Rooy JL (2016) Guidelines for sinkhole and subsidence rehabilitation based on generic geological models of a dolomite environment on the East Rand, South Africa. Journal of African Earth Sciences 117:86-101

Lamont-Black J, et al. (2001) Risk of Subsidence due to Evaporite Solution - A European Prediction Management Scheme. Final Report to European Commission under Framework IV ENV-CT97-0603

Leparmentier AM (2013) Les risques liés aux cavités, l'exemple de la région Parisienne. CFGI - SGF - CNAM. 35 https://www.geosoc.fr/ (In French) 
Li X, Xiao S, Tang H Peng J (2017) A GIS-based monitoring and early warning system for cover-collapse sinkholes in karst terrane in Wuhan, China. Nat. Hazards Earth Syst. Sci. Discuss., doi:10.5194/nhess-2017-22

Malinowska AA, Witkowski WT, Hejmanowski R, Chang L, Leijen FJ, Hanssen RF (2019) Sinkhole occurrence monitoring over shallow abandoned coal mines with satellite-based persistent scatterer interferometry. Engineering Geology 262:

5 https://doi.org/10.1016/j.enggeo.2019.105336

Ozdemir A (2015) Investigation of sinkholes spatial distribution using the weights of evidence method and GIS in the vicinity of Karapinar (Konya, Turkey). Geomorphology 245:40-50

Parise M (2012) A Present Risk from Past Activities: Sinkhole Occurrence above Underground Quarries. Carbonates and Evaporites 27 (2): 109-118. https://doi:10.1007/s13146-012-0088-3

10 Parise M, Vennari C (2013) A Chronological Catalogue of Sinkholes in Italy: The First Step toward a real Evaluation of the Sinkhole Hazard." In Proceedings of the 13th Multidisciplinary. Conference on Sinkholes and the. Engineering and Environmental Impacts of Karst, Carlsbad, pp 383-392.

Pham MT, Briançon L, Dias D, Abdelouhab A (2018) Investigation of load transfer mechanisms in granular platforms reinforced by geosynthetics above cavities. Geotextiles and Geomembranes 46:611-624

15 Poorooshasb HB (2002) Subsidence evaluation of geotextile-reinforced gravel mats bridging a sinkhole, Geosynthetics International 2002, vol. 9, 24p

Popa H, Gaudin O, Garnier J, Thorel L, Pouya A, Reiffsteck P (2003) Interaction fondation superficielle-paroi de soutènement : modélisation expérimentale numérique. Fondsup 2003, Symposium International sur les fondations superficiels, Paris, vol. 1,1. (In French)

20 Potts VJ, Zdravkovic L (2008) Assessment of BS8006:1995 design method for reinforced fill layers above voids, 4th European Geosynthetics conference, Edinburg, $7 \mathrm{p}$

Reuter F, Stoyan D (1993) Sinkholes in carbonate, sulphate, and chloride karst regions: Principles and problems of engineering geological investigations and predictions, with comments for the construction and mining industries. In Beck B F (ed) Applied karst geology. Proceedings of the fourth multidisciplinary conference on sinkholes and the engineering and environmental 25 impacts of karst, Panama City/Florida, pp 3-25

Sartain N, Mian J, O'Riordan N, Storry R (2011) Case study on the assessment of sinkhole risk for the, development of infrastructure over karstic ground, ISGSR 2011 - Vogt, Schuppener, Straub \& Bräu (eds) - (c) 2011 Bundesanstalt für Wasserbau ISBN 978-3-939230-01-4

Schwerdt S, Mexer N, Paul A (2004) Die Bemessung von Geokunststoffbewehrungen zur Ueberbrueckung von

30 Erdeinbruechen (BGE-Verfahren)/The design of geosynthetic reinforcements for protection against surface collapse into underground voids. Bauingenieur, 79. (In German)

Sowers GF (1996) Building on Sinkholes. ASCE Press, New York

Shukla SK, Sivakugan N (2009) Technical note - A general expression for geosynthetic strain due to defelection, Geosynthetics International 2009, vol. 16, 6p 
Terzaghi K (1943) Theoretical Soil Mechanics. John Wiley \& Sons, New York, NY

Theron A, Kemp J, Kleynhans W, Turnbull T (2016) Detection of Sinkhole Precursors Through SAR Interferometry: Radar and Geological Considerations. GRSL-01085-2016

Thierry P, Prunier-Leparmentier AM, Lembezat C, Vanoudheusden E, Vernoux JF (2009) 3D geological modelling at urban 5 scale and mapping of ground movement susceptibility from gypsum dissolution: The Paris example (France). Engineering Geology, 105: 51-64. ff10.1016/j.enggeo.2008.12.010ff. ffhal-00514427f

Thomsen C, Christopherson R (2010) Encounter Geosystems: Interactive Explorations of Earth Using Google Earth. New York

Thornbush MJ (2017) Part 1: Contemporary Challenges and Current Solutions in Sinkhole Occurrence and Mitigation. Journal 10 of Geology \& Geophysics 6:3 https://doi: 10.4172/2381-8719.1000287

Viana PMF, Bueno BS, Costa YD (2008) A simplified method to predict vertical displacements, deformations and tensile stresses in geosynthetics overlying voids, First Pan American Geosynthetics Conference \& Exhibition, 2008, Cancun, Mexico, $9 \mathrm{p}$

Van Eekelen SJM, Bezuijen A, Van Tol AF (2013) An analytical model for arching in piled embankments. Geotextiles and 15 Geomembranes 39:78-102

Villard P, Briançon L (2008) Design of geosynthetic-reinforcements for platforms subjected to localized sinkholes. Can. Geotech. J 45:196-209

Villard P, Huckert A, Briançon L (2016) Load transfer mechanisms in geotextile-reinforced embankments overlying voids: Numerical approach and design. Geotextiles and Geomembranes 44:381-395

20 Waltham T, Bell F, Culshaw M (2005) Sinkholes and subsidence. Springer, Chichester

Weary DJ (2015) The cost of karst subsidence and sinkhole collapse in the United States compared with other natural hazards, Proceedings of the Fourteenth Multidisciplinary Conference, Rochester, Minn.: National Cave and Karst Research Institute, Symposium 5, Carlsbad, N.Mex., pp 433-445, dx.doi.org /10.5038/9780991000951.1062

Wu PC, Yin JH, Feng WQ, Chen WB (2019) Experimental study on geosynthetic-reinforced sand fill over marine clay with 25 or without deep cement mixed soil columns under different loadings. Underground space. 4:340-347. https://doi.org/10.1016/j.undsp.2019.03.001 


\begin{tabular}{|c|c|c|}
\hline $\mathrm{c}$ & $(\mathrm{Pa})$ & Cohesion of the soil \\
\hline$C_{e}$ & $(\%)$ & Expansion coefficient of the soil \\
\hline $\mathrm{D}$ & $(\mathrm{m})$ & Size of the cavity at the GSY level \\
\hline$D_{50}$ & $(\mathrm{~m})$ & Mean diameter of the soil particles \\
\hline$D_{s}$ & $(\mathrm{~m})$ & Surface subsidence diameter \\
\hline $\mathrm{d}$ & $(\mathrm{m})$ & $\begin{array}{l}\text { Complementary length of the GSY so that } 21+2 d \text { is equal to the final length of the GSY over } \\
\text { the cavity }\end{array}$ \\
\hline$d_{s}$ & $(\mathrm{~m})$ & Magnitude of the vertical surface displacement \\
\hline$f(x)$ & $(\mathrm{m})$ & GSY vertical deflexion (displacement) \\
\hline $\mathrm{f}_{\max }$ & $(\mathrm{m})$ & GSY maximum vertical deflexion (displacement) \\
\hline $\mathrm{f}_{\max } \exp$ & $(\mathrm{m})$ & Experimental GSY maximum vertical deflexion (displacement) \\
\hline $\mathrm{f}_{\max }^{\text {ana }}$ & $(\mathrm{m})$ & Analytical GSY maximum vertical deflexion (displacement) \\
\hline $\mathrm{H}$ & $(\mathrm{m})$ & Height of the soil layer over the cavity \\
\hline $\mathrm{J}$ & $(\mathrm{N} / \mathrm{m})$ & Tensile stiffness of the GSY \\
\hline $\mathrm{K}$ & $(-)$ & Earth pressure coefficient \\
\hline $\mathrm{Ka}$ & $(-)$ & Active earth pressure coefficient \\
\hline$\Delta \mathrm{L}$ & $(\mathrm{m})$ & Total increase of the length of GSY over the cavity \\
\hline$l 1$ & $(\mathrm{~m})$ & Width of the zone on which the load is applied on the soil surface \\
\hline $2 l$ & $(\mathrm{~m})$ & Distance between the two punctual loads P acting on the GSY \\
\hline $\mathrm{F}$ & $(\mathrm{N} / \mathrm{m})$ & Punctual load applied on the GSY defined by meter length \\
\hline $\mathrm{p}$ & $\left(\mathrm{N} / \mathrm{m}^{2}\right)$ & Vertical uniform pressure acting on the soil surface above the cavity \\
\hline$q_{0}$ & $\left(\mathrm{~N} / \mathrm{m}^{2}\right)$ & Vertical uniform pressure acting on the GSY in the anchorage zones \\
\hline $\mathrm{S}$ & $\mathrm{m}$ & Maximum vertical displacement observed on the soil surface \\
\hline$q(x)$ & $\left(\mathrm{N} / \mathrm{m}^{2}\right)$ & Vertical uniform load distribution acting on the GSY over the cavity \\
\hline $\mathrm{q}_{1}$ & $\left(\mathrm{~N} / \mathrm{m}^{2}\right)$ & Maximal vertical load acting on the GSY for each load distribution \\
\hline $\mathrm{r}$ & & Constant defined as $r=\sqrt{q_{0}\left(\tan \delta_{i}+\tan \delta_{s}\right) /\left(J U_{0}\right)}$ \\
\hline SF & & Fontainebleau Sand soil \\
\hline SK & & Fontainebleau Sand + Kaolin soil \\
\hline $\mathrm{T}_{\mathrm{A}}$ & $(\mathrm{N} / \mathrm{m})$ & Tensile force to be mobilized in the GSY anchorage areas \\
\hline $\mathrm{T}(\mathrm{x})$ & $(\mathrm{N} / \mathrm{m})$ & Tensile force in the GSY above the cavity \\
\hline $\mathrm{T}_{\mathrm{H}}$ & $(\mathrm{N} / \mathrm{m})$ & horizontal component of the tensile force in the part of the GSY above the cavity \\
\hline $\mathrm{T}_{\mathrm{V}}(\mathrm{x})$ & $(\mathrm{N} / \mathrm{m})$ & vertical component of the tensile force in the part of the GSY above the cavity \\
\hline $\mathrm{T}_{\max }$ & $(\mathrm{N} / \mathrm{m})$ & Maximal tensile force acting on the GSY sheet \\
\hline
\end{tabular}




$\begin{array}{lll}U_{0} & (\mathrm{~m}) & \text { Displacement value required to mobilize the maximum shear stress at the soil - GSY interface } \\ U_{A} & (\mathrm{~m}) & \text { Horizontal relative displacement at the soil - GSY interface at the edge of the cavity } \\ \mathrm{w}(\mathrm{x}) & (\mathrm{m}) & \text { Vertical displacement of the soil surface } \\ \mathrm{z}(\mathrm{x}) & (\mathrm{m}) & \text { Vertical displacement of the GSY } \\ \alpha & & \text { Constant defined as } \alpha=U_{A} / U_{0} \text { if } U_{A} \leq U_{0} \text { and } \alpha=1 \text { if } U_{A}>U_{0} \\ \delta_{i} & \left({ }^{\circ}\right) & \text { Lower friction angle of the soil-GSY interface } \\ \delta_{s} & \left({ }^{\circ}\right) & \text { Upper friction angle of the soil-GSY interface } \\ \beta & (-) & \text { Tangent of the inclination angle of the GSY at the edge of the cavity } \beta=\frac{d z(x=D / 2)}{d x} \\ \varepsilon(x) & (\%) & \text { Tensile strain in the GSY above the cavity } \\ \varepsilon_{\mathrm{w}} & (\%) & \text { Initial strain of the sheet due to its initial ripples in the GSY above the cavity } \\ \sigma_{\mathrm{vg}} & \left(\mathrm{N} / \mathrm{m}^{2}\right) & \text { Vertical stress applied on GSY calculated using Terzaghi's equation } \\ \tau_{0} & \left(\mathrm{~N} / \mathrm{m}^{2}\right) & \text { Shear resistance of the GSY interfaces with both the soil above and below the GSY in cas the } \\ & & \text { normal stress is } q_{0} \tau_{0}=q_{0}\left(\tan \delta_{i}+\tan \delta_{s}\right) \\ \gamma & \left(\mathrm{N} / \mathrm{m}^{3}\right) & \text { Density of the soil unit weight } \\ \phi & \left({ }^{\circ}\right) & \text { Soil internal friction angle of the soil }\end{array}$




\section{List of Tables:}

Table 1. Description of damages related to the dimension of the sinkhole in urban land

Table 2. Risk treatment solutions for subsidence and sinkhole hazard

Table 3. Main equations used as a function of the load distribution acting on the GSY sheet

5 Table 4. Principal characteristics of the instrumentation, *precision measured in the conditions of the experiments

Table 5. Load shape distributions comparison between analytical and experimental results

Table 6. Comparison between analytical and experimental results assuming $\mathrm{D} \varepsilon_{\mathrm{w}}=4 \mathrm{~mm}$

Table 7. Input parameters of Huckert et al model (2016), and comparison of the experimental and analytical deflexion of GSY 


\begin{tabular}{|l|l|l|}
\hline Diameter of the sinkhole $(\mathbf{m})$ & Level of risk & Description of damages \\
\hline$<1 \mathrm{~m}$ or depression on the surface & Very Low & $\begin{array}{l}\text { Non possibility of death or injury of person } \\
\text { Physical losses very limited, cost of damage }<10 \mathrm{k} € \\
\text { Non-economic impact }\end{array}$ \\
\hline$>1 \mathrm{~m}$ and $<3 \mathrm{~m}$ & Low to moderate & $\begin{array}{l}\text { Partial degradation of the structures } \\
\text { Limited injuries of persons } \\
\text { Limited economic impact }<100 \mathrm{k} €\end{array}$ \\
\hline$>3 \mathrm{~m}$ and $<5 \mathrm{~m}$ & Moderate to severe & $\begin{array}{l}\text { Partial severe degradation of the structures } \\
\text { Limited injuries of persons } \\
\text { Important economic impact }>100 \mathrm{k} €\end{array}$ \\
\hline $\begin{array}{l}\text { Or/and several sinkholes with small } \\
\text { diameter }\end{array}$ & Very Severe & $\begin{array}{l}\text { Many casualties or injuries } \\
\text { Very large social and economic impact }>1 \mathrm{M} € \\
\text { Destructions of houses and infrastructures }\end{array}$ \\
\hline
\end{tabular}

Table 1. Description of damages related to the dimension of the sinkhole in urban land 


\begin{tabular}{|c|c|c|c|c|c|}
\hline Method & Land use & Execution method & Effects & $\begin{array}{l}\text { Residual } \\
\text { hazard/risk }\end{array}$ & References \\
\hline $\begin{array}{l}\text { Total backfilling - } \\
\text { grouting }\end{array}$ & $\begin{array}{l}\text { Parks, roads, } \\
\text { existing and new } \\
\text { buildings }\end{array}$ & $\begin{array}{l}\text { Accessible cavities: using vehicles } \\
\text { Non-accessible: injection with mortar or } \\
\text { equivalent product from the surface }\end{array}$ & $\begin{array}{l}\text { Suppression of the } \\
\text { hazard }\end{array}$ & $\begin{array}{l}\text { Residual } \\
\text { subsidence }\end{array}$ & $\begin{array}{l}\text { Sowers } 1986 \\
\text { Kleinhans and Van Rooy } 2016\end{array}$ \\
\hline Cavity consolidation & $\begin{array}{l}\text { Parks, roads, } \\
\text { existing and new } \\
\text { buildings }\end{array}$ & $\begin{array}{l}\text { Accessible cavities: Bolts, shotcrete, } \\
\text { additional support/pillars }\end{array}$ & $\begin{array}{l}\text { Reduction of the hazard } \\
\text { level }\end{array}$ & $\begin{array}{l}\text { Long term } \\
\text { collapse - } \\
\text { subsidence }\end{array}$ & Ineris 2007, IFSTTAR 2014 \\
\hline Partial backfilling & $\begin{array}{l}\text { Parks, secondary } \\
\text { roads }\end{array}$ & $\begin{array}{l}\text { Accessible cavities: using vehicles } \\
\text { Non-accessible: injection of mortar or } \\
\text { equivalent product from the surface }\end{array}$ & $\begin{array}{l}\text { Reduction of the hazard } \\
\text { level }\end{array}$ & $\begin{array}{l}\text { Residual } \\
\text { subsidence }\end{array}$ & Al Heib et al. 2010 \\
\hline $\begin{array}{l}\text { Parachute system: } \\
\text { soil reinforced by } \\
\text { GSY }\end{array}$ & $\begin{array}{l}\text { Parks, roads and } \\
\text { networks, railways }\end{array}$ & Installation of GSY over the cavity zones & $\begin{array}{l}\text { Reduction of the hazard } \\
\text { level }\end{array}$ & Subsidence & $\begin{array}{l}\text { Delmas and Gourc, } 2017 \text {; } \\
\text { Cooper and Saunders } 2002\end{array}$ \\
\hline $\begin{array}{l}\text { Reinforcement of } \\
\text { the soil }\end{array}$ & $\begin{array}{l}\text { Parks new and } \\
\text { existing structures }\end{array}$ & Piles, micro-piles and rigid inclusions & $\begin{array}{l}\text { Reduction of the } \\
\text { consequences of the } \\
\text { collapse }\end{array}$ & Slight damages & Ineris 2007, IFSTTAR 2014 \\
\hline Special foundations & $\begin{array}{l}\text { New constructions, } \\
\text { roads, railways }\end{array}$ & Raft reinforced foundation & $\begin{array}{l}\text { Reduction of the } \\
\text { consequences of the } \\
\text { collapse }\end{array}$ & $\begin{array}{l}\text { Subsidence } \\
\text { nearby the non- } \\
\text { treated zones }\end{array}$ & $\begin{array}{l}\text { Reuter and Stoyan 1993; Cooper } \\
\text { and Calow1998; Waltham et al. } \\
2005\end{array}$ \\
\hline $\begin{array}{l}\text { Zone accessibility } \\
\text { regulation }\end{array}$ & $\begin{array}{l}\text { Non-accessible } \\
\text { zones }\end{array}$ & Fenced & & $\begin{array}{l}\text { Subsidence and } \\
\text { sinkhole }\end{array}$ & Ineris 2019, IFSTTAR 2014 \\
\hline $\begin{array}{l}\text { Monitoring and } \\
\text { using alarm system }\end{array}$ & $\begin{array}{l}\text { Parks, Roads and } \\
\text { infrastructure }\end{array}$ & $\begin{array}{l}\text { Underground collapse and surface } \\
\text { movements and deformation }\end{array}$ & $\begin{array}{l}\text { Reduce the risk of } \\
\text { fatalities }\end{array}$ & $\begin{array}{l}\text { Subsidence and } \\
\text { sinkhole }\end{array}$ & $\begin{array}{l}\text { Balland et al. 2009, } \\
\text { Theron et al. 2016, Li et al. } \\
2017 \text {, } \\
\text { Malinowska et al. } 2019\end{array}$ \\
\hline
\end{tabular}

Table 2. Risk treatment solutions for subsidence and sinkhole hazard 


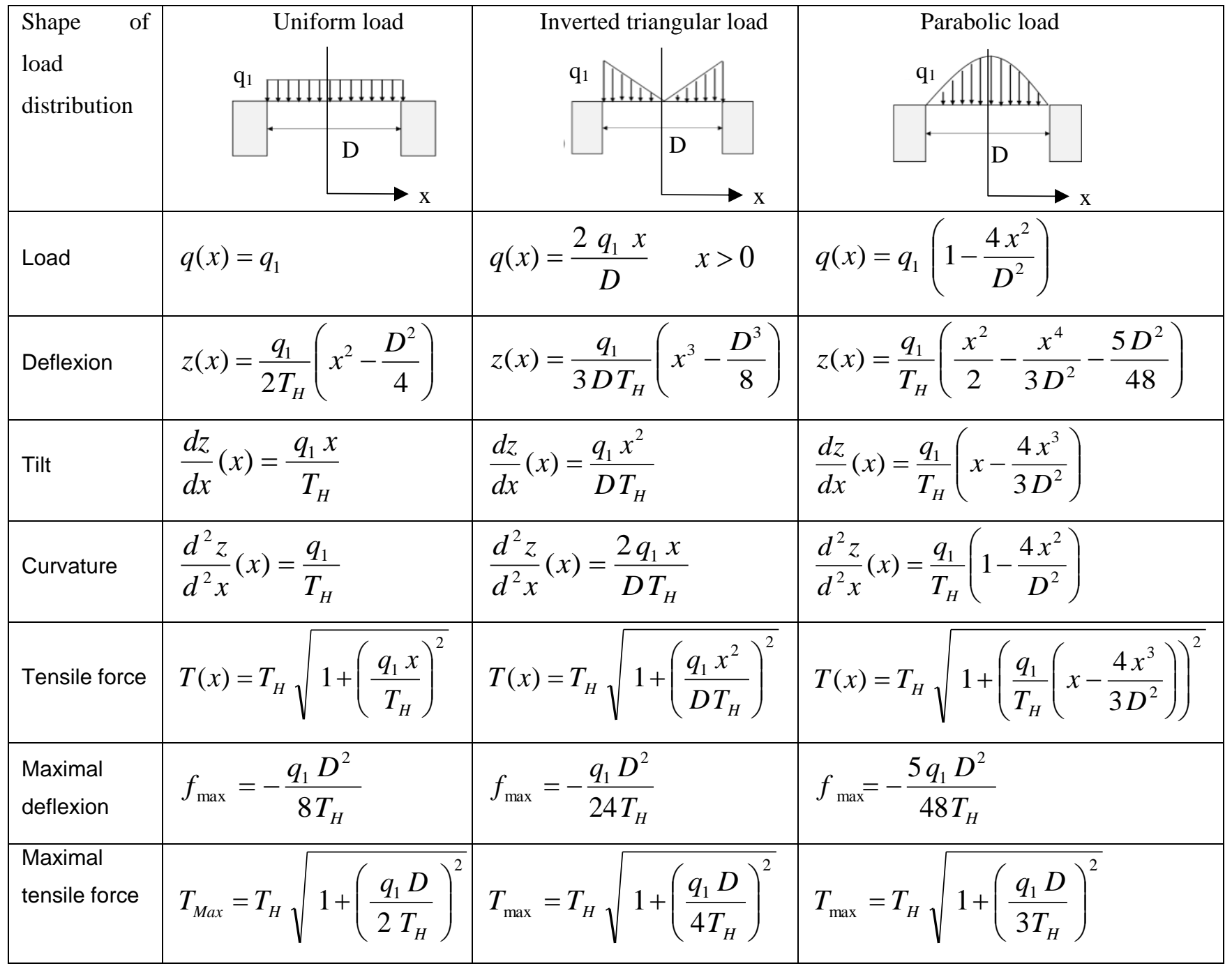

Table 3. Main equations used as a function of the load distribution acting on the GSY sheet 


\begin{tabular}{|c|c|c|c|c|}
\hline Instrument type & Model & Objective & Precision* & Comments \\
\hline Cameras & Kodak-KAI-4022 & $\begin{array}{l}\text { Determination of } \\
\text { the induced 3D } \\
\text { ground surface } \\
\text { displacement field }\end{array}$ & $0.05 \mathrm{~mm}$ & $\begin{array}{l}\text { Careful verification of the light } \\
\text { conditions during the experiment } \\
\text { Calibration of the Digital Image } \\
\text { Correlation software }\end{array}$ \\
\hline Pressure cell & $\begin{array}{l}\text { Arduino } \\
62 * 62 * 26 \mathrm{~mm}\end{array}$ & $\begin{array}{l}\text { Determination of } \\
\text { the vertical stress } \\
\text { transfer }\end{array}$ & $\begin{array}{l}0.5 \% \text { of the } \\
\text { applied load }\end{array}$ & $\begin{array}{l}\text { Calibration before starting the } \\
\text { measurements }\end{array}$ \\
\hline Radar & $\begin{array}{l}\text { VL6180X (Flightsense) } \\
50 * 50 * 10 \mathrm{~mm}\end{array}$ & $\begin{array}{l}\text { Measurement of } \\
\text { the normal } \\
\text { distance between } \\
\text { the trapdoor and } \\
\text { the deflected GSY }\end{array}$ & $2 \mathrm{~mm}$ & $\begin{array}{l}\text { Preparation of the GSY in order to } \\
\text { have a good reflection of the radar } \\
\text { light on its surface }\end{array}$ \\
\hline
\end{tabular}

Table 4. Principal characteristics of the instrumentation, *precision measured in the conditions of the experiments

\begin{tabular}{|c|c|c|c|c|c|c|c|}
\hline $\begin{array}{c}\text { Self- } \\
\text { weight } \\
\left(\mathrm{kN} / \mathbf{m}^{2}\right)\end{array}$ & $\begin{array}{c}\text { Overload } \\
\left(\mathrm{kN} / \mathrm{m}^{2}\right)\end{array}$ & $\begin{array}{c}\sigma_{\mathrm{vg}} \\
\left(\mathrm{kN} / \mathrm{m}^{2}\right)\end{array}$ & Parameters & Experiment & Uniform & $\begin{array}{l}\text { Inverted } \\
\text { triangular }\end{array}$ & Parabolic \\
\hline \multirow{3}{*}{1.75} & \multirow{3}{*}{0} & \multirow{3}{*}{1.75} & $f_{\max }(m m)$ & 41.6 & 42.35 & 29.4 & 53.61 \\
\hline & & & $\mathrm{T}_{\max }(\mathrm{kN} / \mathrm{m})$ & I & 1.37 & 0.99 & 1.8 \\
\hline & & & $\mathrm{U}_{\mathrm{A}}(\mathrm{mm})$ & I & 2.73 & 1.65 & 4.35 \\
\hline \multirow{3}{*}{1.75} & \multirow{3}{*}{0.59} & \multirow{3}{*}{2.24} & $f_{\max }(m m)$ & 53.6 & 46.91 & 32.35 & 59.66 \\
\hline & & & $\mathrm{T}_{\max }(\mathrm{kN} / \mathrm{m})$ & 1 & 1.59 & 1.16 & 2.09 \\
\hline & & & $\mathrm{U}_{\mathrm{A}}(\mathrm{mm})$ & I & 3.45 & 2.05 & 5.55 \\
\hline \multirow{3}{*}{1.75} & \multirow{3}{*}{1.37} & \multirow{3}{*}{2.89} & $\mathrm{f}_{\max }(\mathrm{mm})$ & 71.55 & 52.33 & 35.87 & 66.82 \\
\hline & & & $\mathrm{T}_{\max }(\mathrm{kN} / \mathrm{m})$ & 1 & 1.87 & 1.37 & 2.45 \\
\hline & & & $\mathrm{U}_{\mathrm{A}}(\mathrm{mm})$ & I & 4.44 & 2.6 & 7.15 \\
\hline \multirow{3}{*}{1.75} & \multirow{3}{*}{2.16} & \multirow{3}{*}{3.54} & $\mathrm{f}_{\max }(\mathrm{mm})$ & 82.75 & 57.22 & 39.06 & 73.23 \\
\hline & & & $\mathrm{T}_{\max }(\mathrm{kN} / \mathrm{m})$ & 1 & 2.13 & 1.56 & 2.78 \\
\hline & & & $\mathrm{U}_{\mathrm{A}}(\mathrm{mm})$ & I & 5.44 & 3.16 & 8.74 \\
\hline
\end{tabular}

Table 5. Load shape distributions comparison between analytical and experimental results (SF1) (“/”" = not measured) 


\begin{tabular}{|c|c|c|c|c|c|c|c|}
\hline $\begin{array}{c}\text { Self- } \\
\text { weight } \\
\left(\mathbf{k N} / \mathbf{m}^{2}\right)\end{array}$ & $\begin{array}{c}\text { Overload } \\
\left(\mathbf{k N} / \mathbf{m}^{2}\right)\end{array}$ & $\begin{array}{c}\boldsymbol{\sigma}_{\mathbf{v g}} \\
\left(\mathbf{k N} / \mathbf{m}^{2}\right)\end{array}$ & $\begin{array}{c}\text { Shape } \\
\text { distribution }\end{array}$ & $\begin{array}{c}\text { Experiment } \\
\mathbf{f}_{\max }(\mathbf{m m})\end{array}$ & $\begin{array}{c}\text { Analytic } \\
\mathbf{f}_{\mathbf{m a x}}(\mathbf{m m})\end{array}$ & $\begin{array}{c}\text { Analytic } \\
\mathbf{T}_{\mathbf{m a x}} \\
(\mathbf{k N} / \mathbf{m})\end{array}$ & $\begin{array}{c}\text { Analytic } \\
\mathbf{U}_{\mathbf{A}}(\mathbf{m m})\end{array}$ \\
\hline 1.75 & 0 & 1.75 & $\begin{array}{c}\text { Inverted } \\
\text { triangular }\end{array}$ & 41.6 & 36.99 & 0.81 & 3.67 \\
\hline 1.75 & 0.59 & 2.24 & Uniform & 53.6 & 53.8 & 1.42 & 5.49 \\
\hline 1.75 & 1.37 & 2.89 & Parabolic & 71.55 & 72.34 & 2.29 & 9.16 \\
\hline 1.75 & 2.16 & 3.54 & Parabolic & 82.75 & 78.41 & 2.63 & 10.76 \\
\hline 1.75 & 0 & 1.75 & Uniform & 77.2 & 68.7 & 0.91 & 10.76 \\
\hline
\end{tabular}

Table 6. Comparison between analytical and experimental results assuming $D \varepsilon_{w}=4 \mathrm{~mm}$

\begin{tabular}{|c|c|c|c|c|c|c|}
\hline & $\begin{array}{c}\mathbf{J} \\
(\mathbf{k N} / \mathbf{m})\end{array}$ & $\mathbf{2 l} \mathbf{( m )}$ & $\mathbf{2 F}(\mathbf{k N} / \mathbf{m})$ & $\mathbf{U}_{\mathbf{A}}(\mathbf{m m})$ & $\begin{array}{c}\mathbf{f} \text { exp } \\
(\mathbf{m m})\end{array}$ & $\begin{array}{c}\mathbf{f}_{\text {ana }} \text { (Huckert) } \\
(\mathbf{m m})\end{array}$ \\
\hline Analytic1 & 170 & 0.15 & 3.9 & 1,375 & 56.6 & 62.1 \\
\hline Analytic 2 & 170 & 0.15 & 4.2 & 1,375 & 56.6 & 62.5 \\
\hline Analytic 3 & 170 & 0.15 & 3.9 & 0 & 56.6 & 57.9 \\
\hline
\end{tabular}

5

Table 7. Input parameters of Huckert et al model (2016), and comparison of the experimental and analytical deflexion of GSY 
List of Figures:

Figure 1. a) Karst regions over the world (Thomsen and Christopher, 2010, and b) Normandie areas submitted to man-made cavities

5 Figure 2. Degradation of the underground mines - roof (a) and pillar (b) and occurrence of sinkhole (c) (Source: Ineris)

Figure 3. Examples of sinkholes in the principal European capitals a) Paris, b) London and c) Rome (Parise, 2012, Edmonds, 2018, Leparmentier, 2013).

Figure 4. Behaviour of GSY over the cavity and fundamental involved mechanisms

Figure 5. Proposed geometry for cohesive soils

10 Figure 6. a) Description of the 3D-1-g physical model, b) view of the radar, c) view of the pressure cell and d) view of the cameras

Figure 7. Location of the radars (R1 to R7) under the cavity and pressure cells (C1-C13) around the cavity

Figure 8. 3D soil vertical displacements (W) after cavity opening for granular soil (SF1 and SF2) and SF2

Figure 9. Vertical displacements $\mathrm{f}(\mathrm{x})$ of the GSY and surface subsidence $\mathrm{w}(\mathrm{x})$ after the cavity formation for granular soil (SF1

15 and SF2)

Figure 10. a) Ration of initial stress, and b) final stress to theoretical lithostatic pressure $\gamma \mathrm{H}$ (with $\gamma$; the density of the soil and $\mathrm{H}$ : the thickness of the soil layer) at the base of the soil layer for Fontainebleau soil (SF1)

Figure 11. Evolution of the vertical stress ratio during loading - granular soil (SF1)

Figure 12. Stress distribution on the GSY above the cavity in 3D (a) uniform distribution, (b) Inverted triangular and (c) 20 parabolic distribution.

Figure 13. Stress distribution on the GSY above the cavity in 2D (a) uniform distribution, (b) Inverted triangular (c) parabolic distribution.

Figure 14. Comparison of experimental and analytical GSY vertical displacements after cavity opening - granular soil (SF1 and SF2)

25 Figure 15. Evolution of the GSY displacements during loading and unloading for SF1 and SF2

Figure 16. Evolution of the deflexion, comparison between analytical and experimental results

Figure 17. Vertical GSY displacement comparisons between experimental and analytical results

Figure 18. a) Ratio of initial stress, and b) final stress to $\gamma \mathrm{H}$ (with $\gamma$ : the density of the soil and $\mathrm{H}$ : the thickness of the soil layer) at the base of the soil layer for cohesive soil (Sand-kaolin, SK1)

30 Figure 19. Comparison of load transfer in cases of granular soil (average of SF1 and SF2) and cohesive soils (average SK1 and SK2).

Figure 20. (A) Collapsed zones of the cohesive soil layer following a surface loading and (B) Geometry of the collapsed block for cohesive soil (Al Heib et al. 2020).

Figure 21. Considered geometries of the soil blocks included in the assessment of force F in the analytical model: a) lower 35 limit b) upper limit

Figure 22. Comparison of the deflection of the GSY for SK1 and SK2 after failure (loading $=550 \mathrm{~N}$ )

Figure 23. Comparison of the maximum deflection of the GSY for SF1 and SK1 during the different phases of the loading tests 

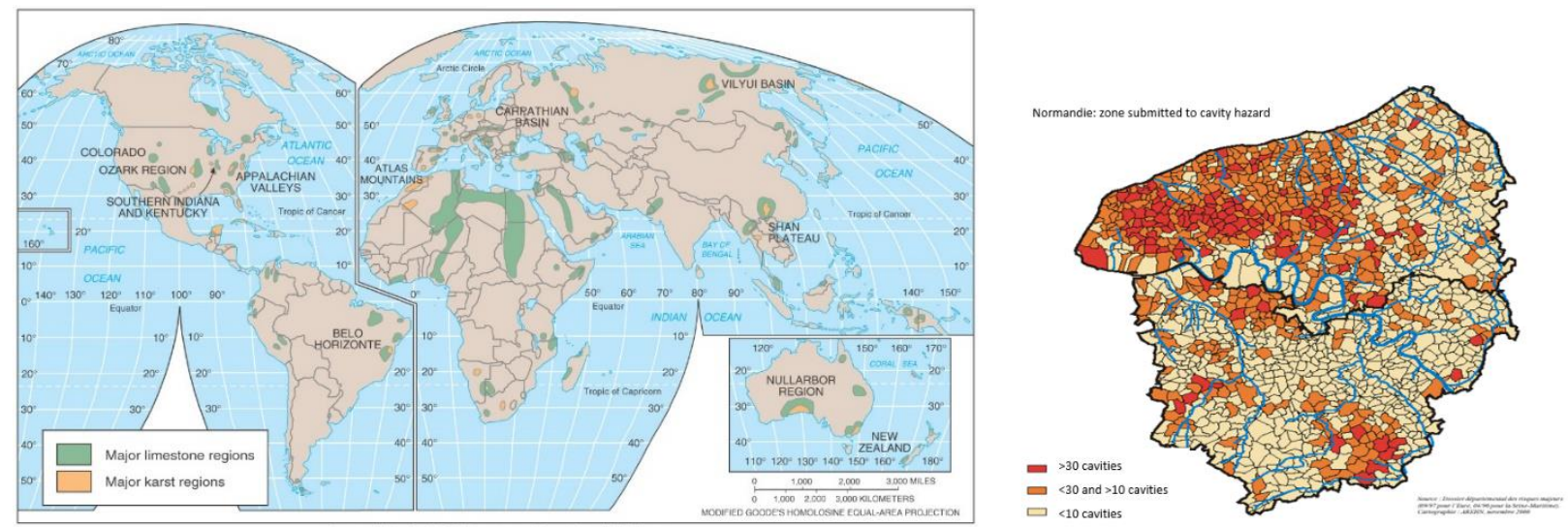

Figure 1. a) Karst regions over the world (Thomsen and Christopher, 2010, and b) Normandie areas submitted to man-made cavities (Brgm, 2005)
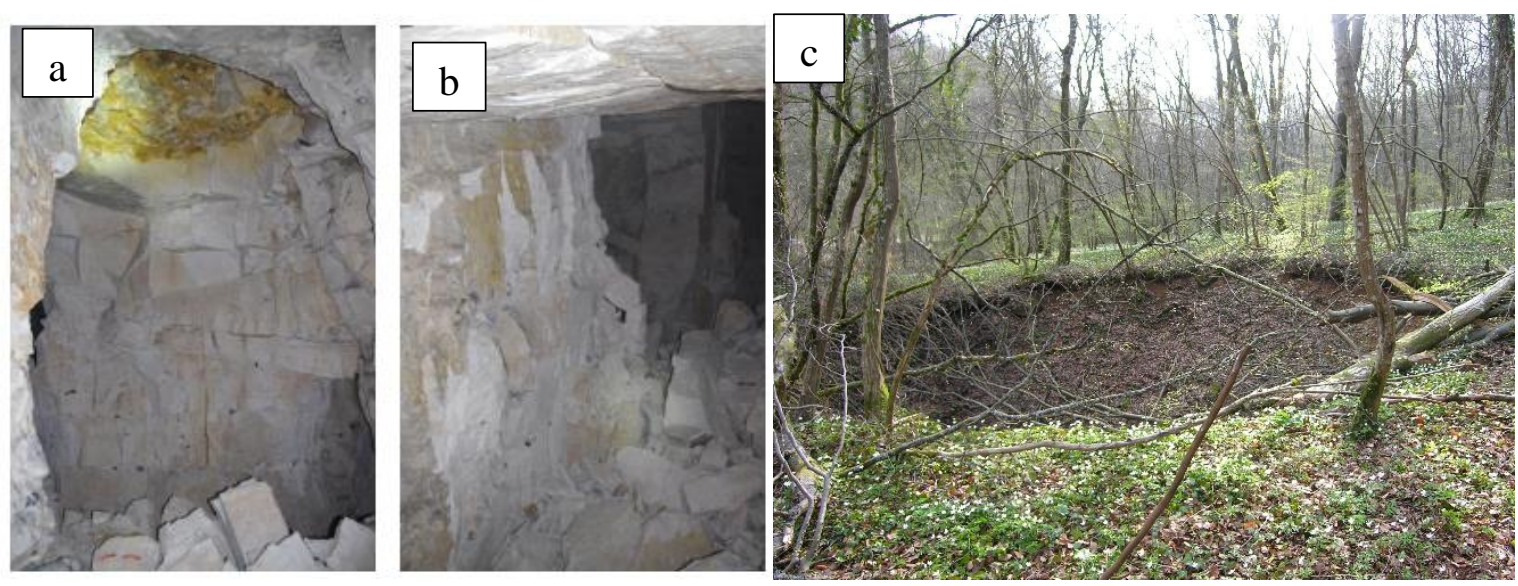

Figure 2. Degradation of the underground mines - roof (a) and pillar (b) and occurrence of sinkhole (c) (Source: Ineris)
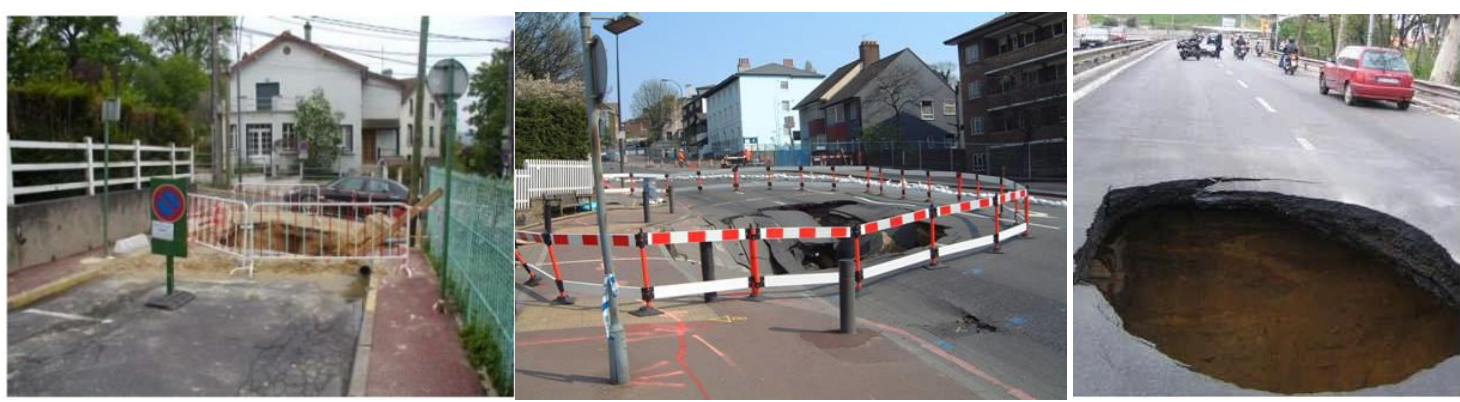

Figure 3. Examples of sinkholes in the principal European capitals a) Paris, b) London and c) Rome (Parise, 2012, Edmonds, 2018, 10 Leparmentier, 2013). 


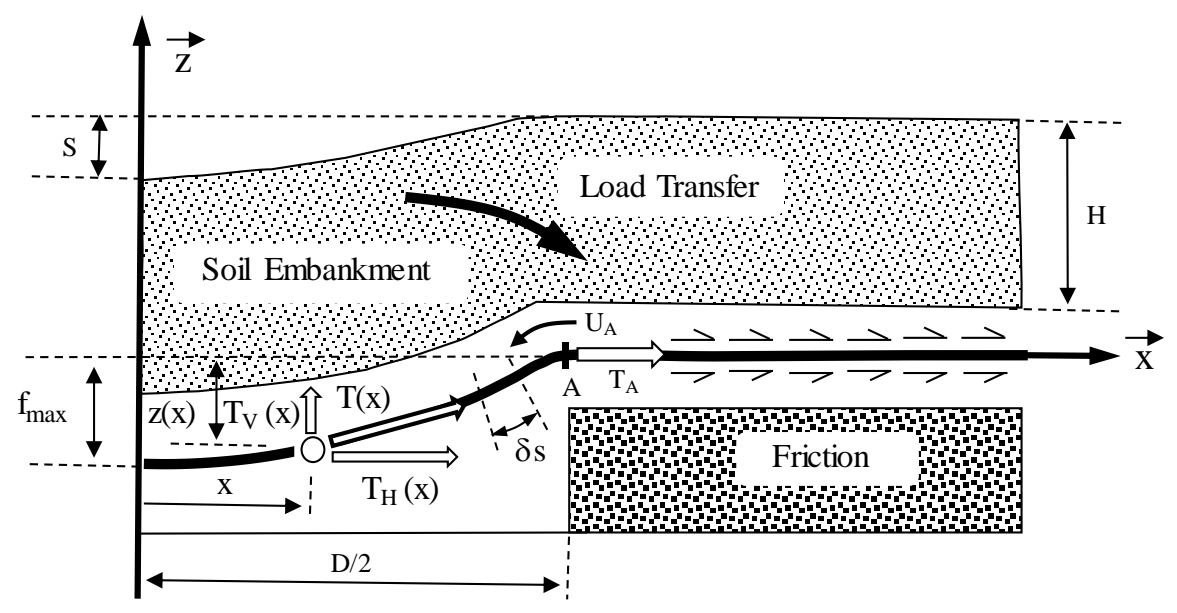

5 Figure 4. Behaviour of GSY over the cavity and fundamental involved mechanisms

10

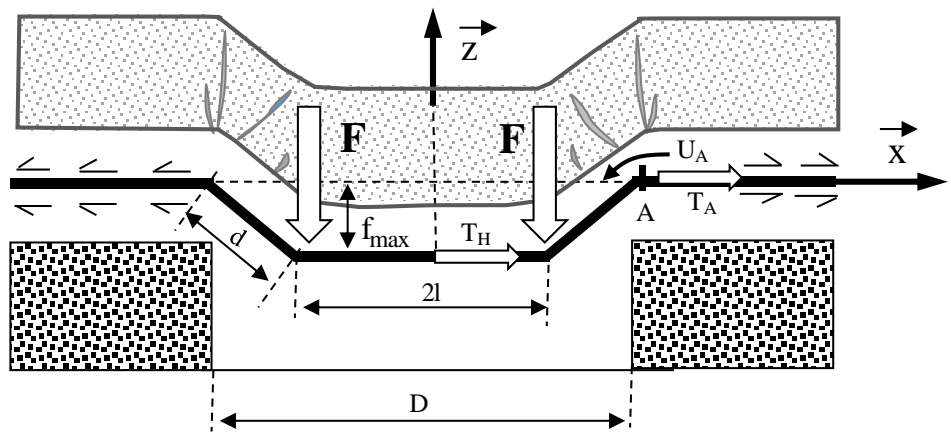

15

Figure 5. Proposed geometry for cohesive soils 

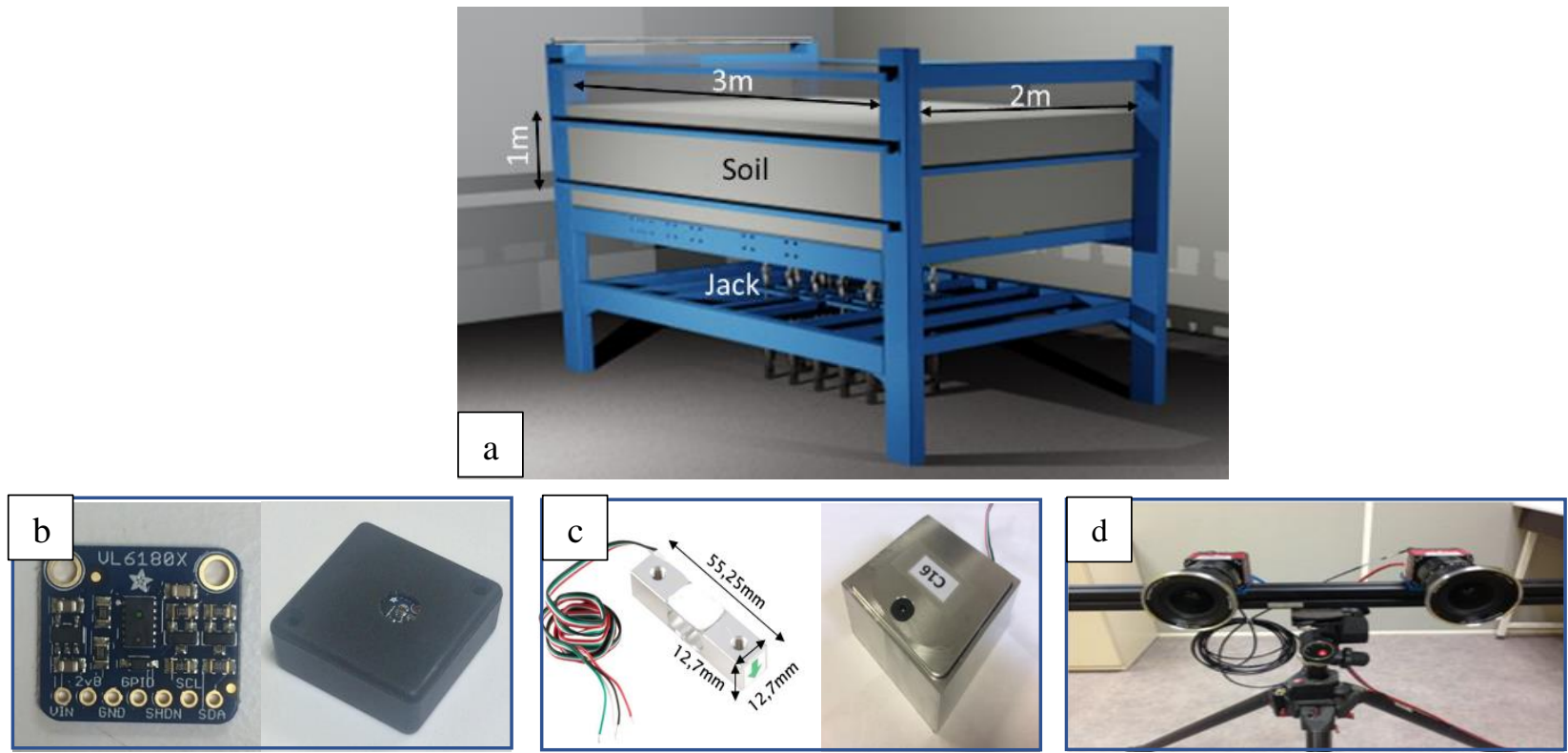

Figure 6. a) Description of the 3D-1-g physical model, b) view of the radar, c) view of the pressure cell and d) view of the cameras 5 (Al Heib et al. 2020).

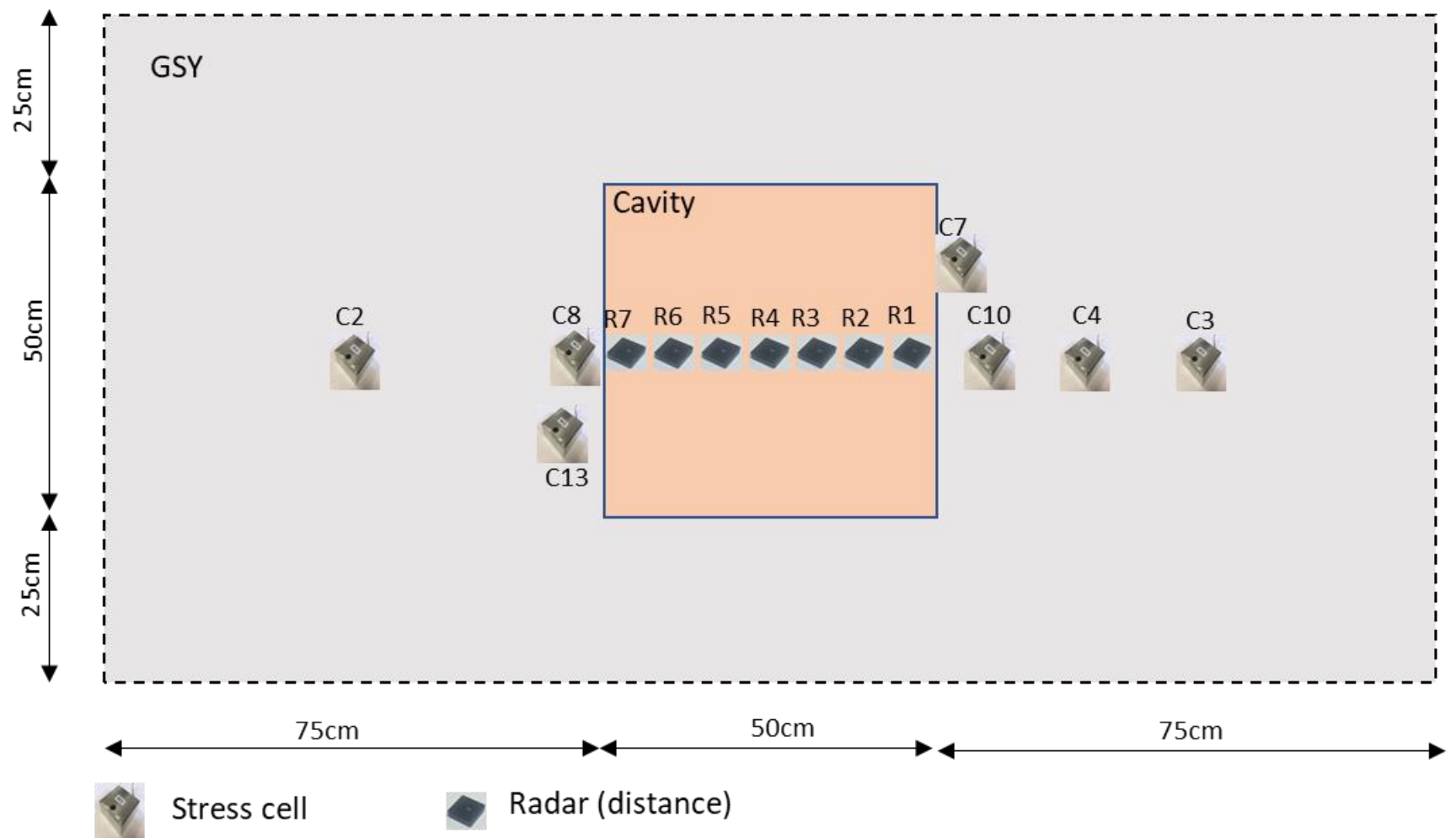

Figure 7. Location of the radars (R1 to R7) under the cavity and pressure cells (C1-C13) around the cavity (Al Heib et al. 2020) 

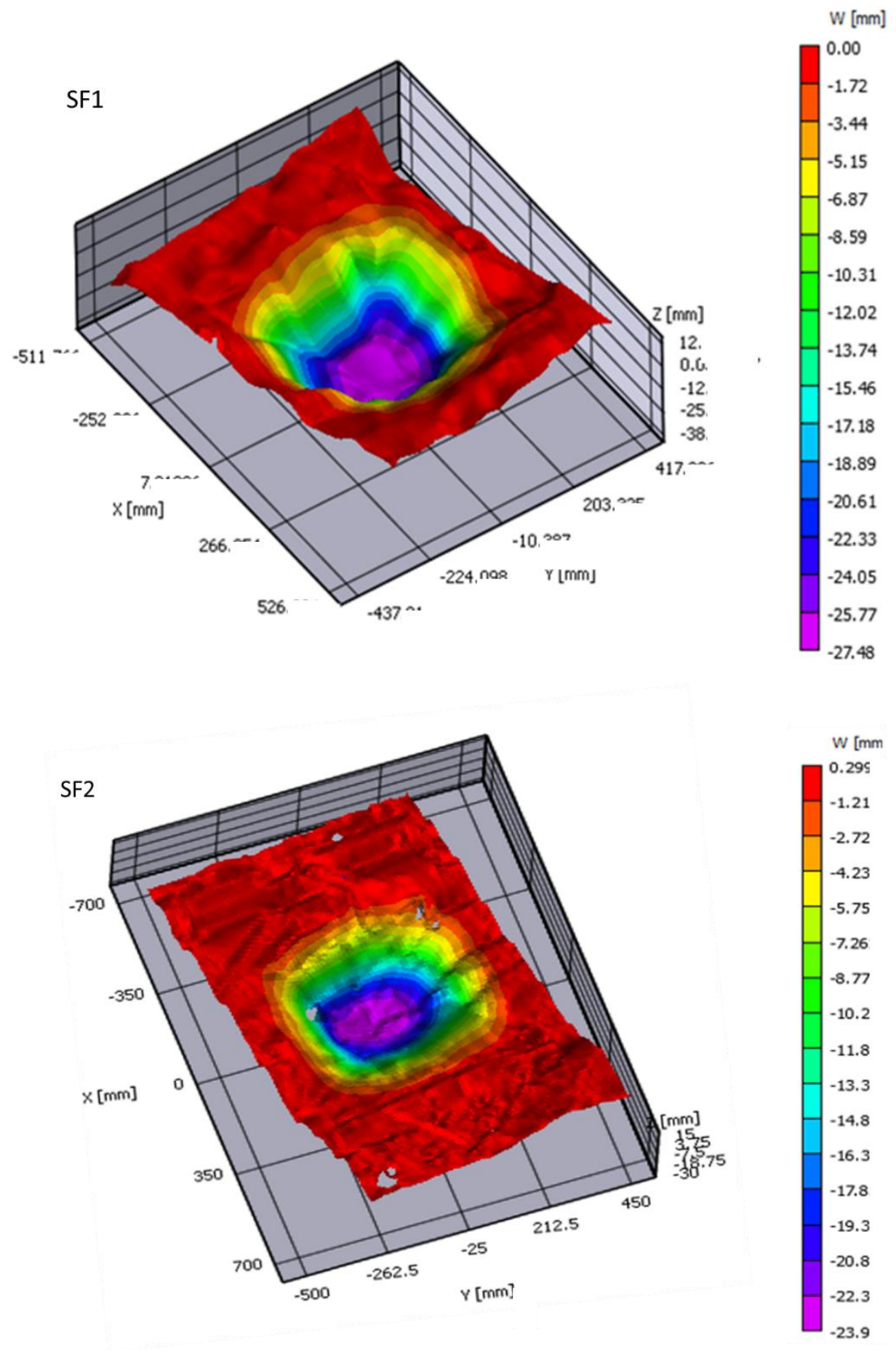

Figure 8. 3D soil vertical displacements (W) after cavity opening for granular soil (SF1 and SF2) 


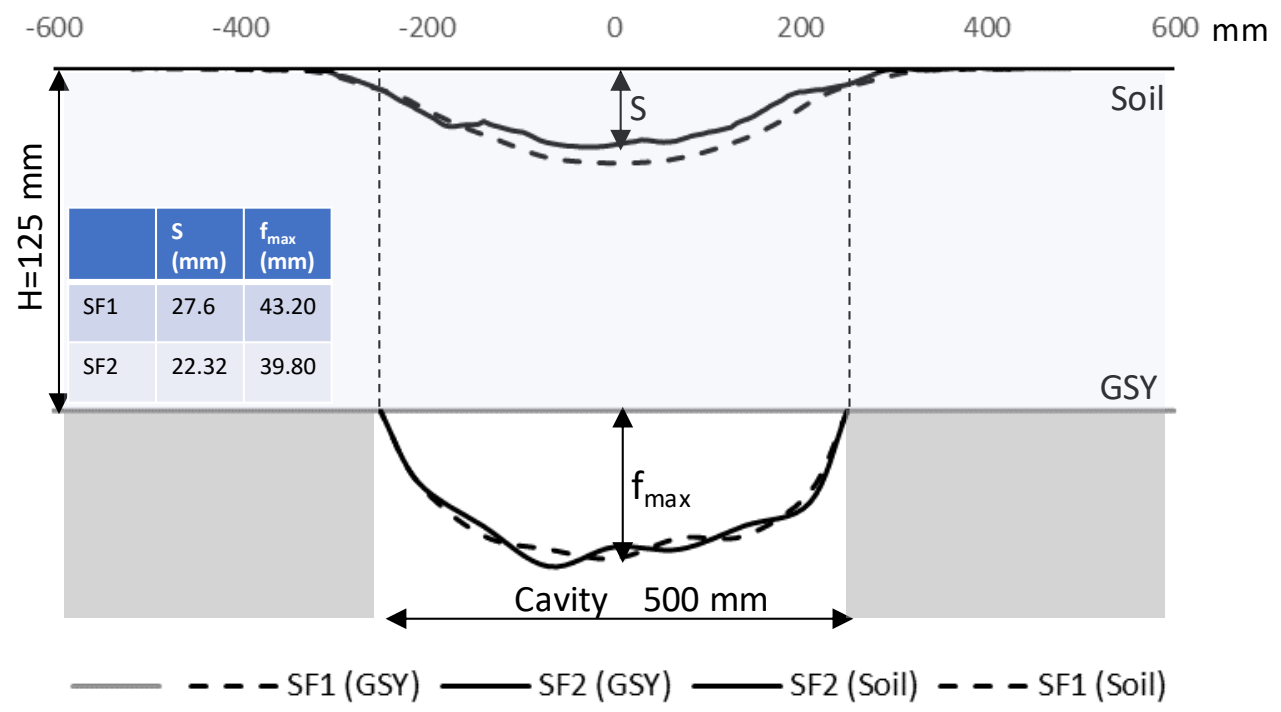

Figure 9. Vertical displacements $\mathbf{f}(\mathbf{x})$ of the GSY and surface subsidence $w(x)$ after the cavity formation for granular soil (SF1 and SF2)
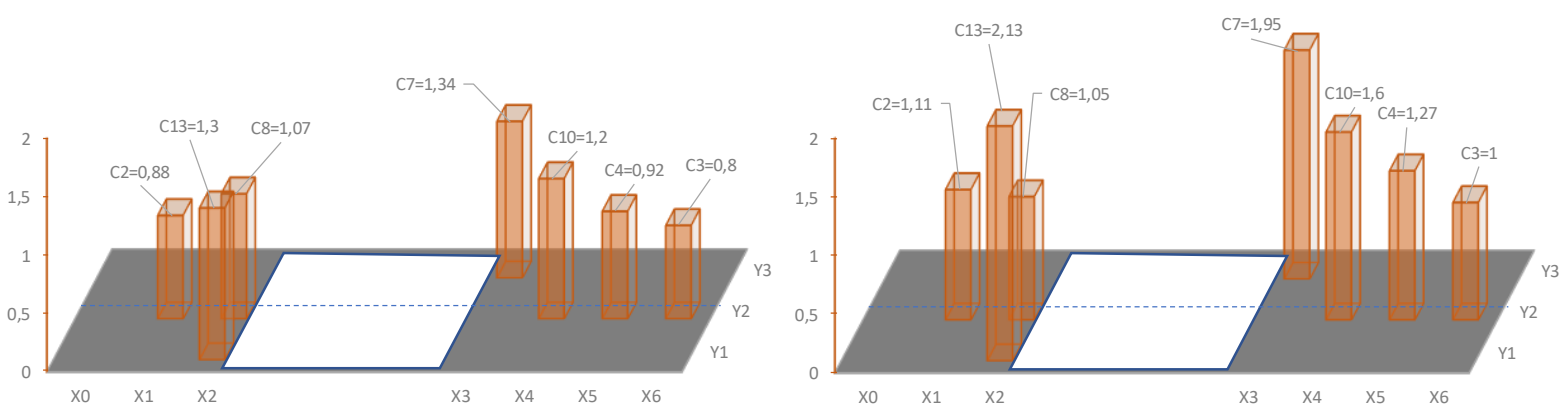

5 Figure 10. a) Ration of initial stress, and b) final stress to theoretical lithostatic pressure $\gamma \mathrm{H}$ (with $\gamma$; the density of the soil and $\mathrm{H}$ : the thickness of the soil layer) at the base of the soil layer for Fontainebleau soil (SF1) 


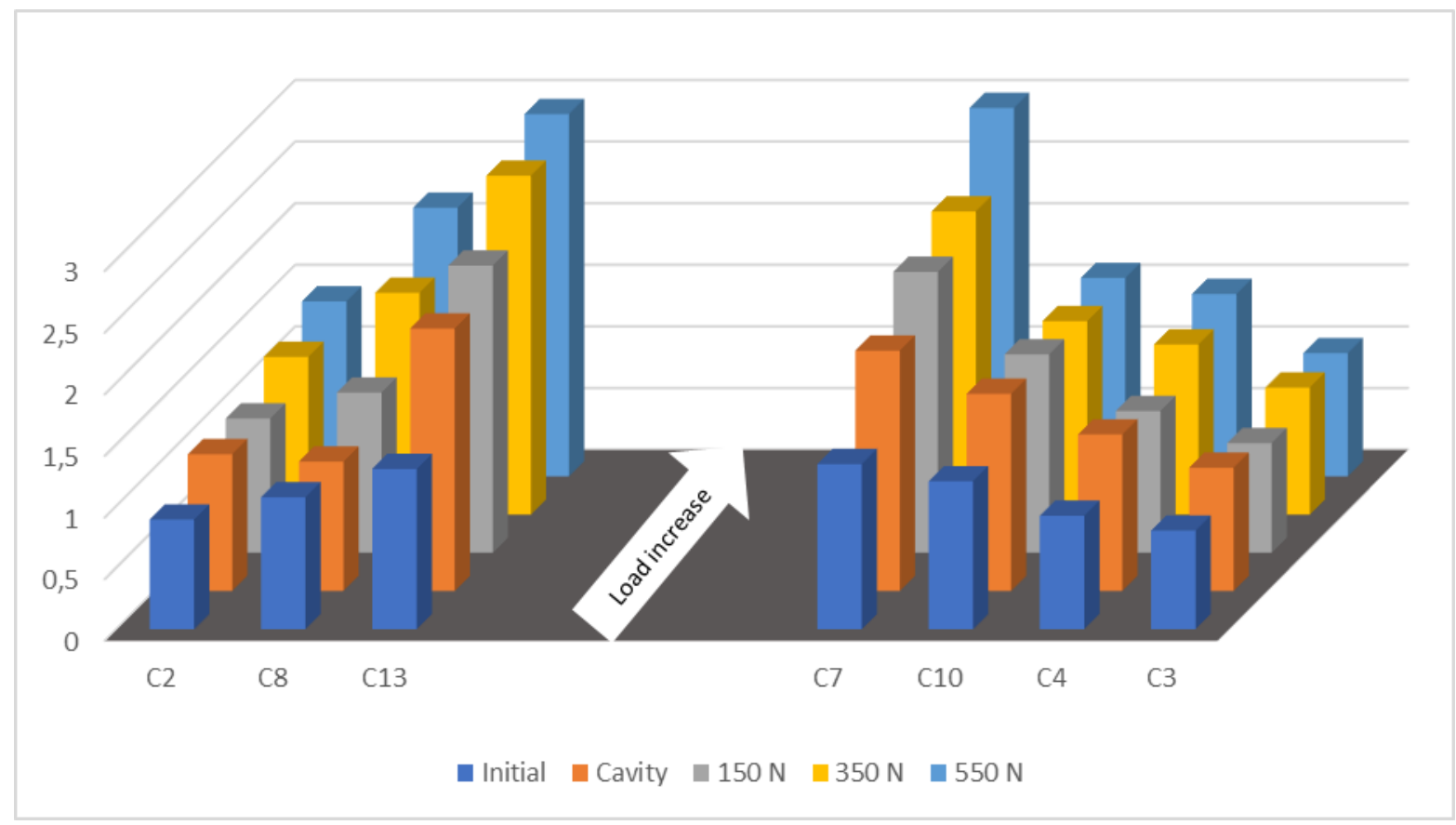

Figure 11. Evolution of the vertical stress ratio during loading - granular soil (SF1) 

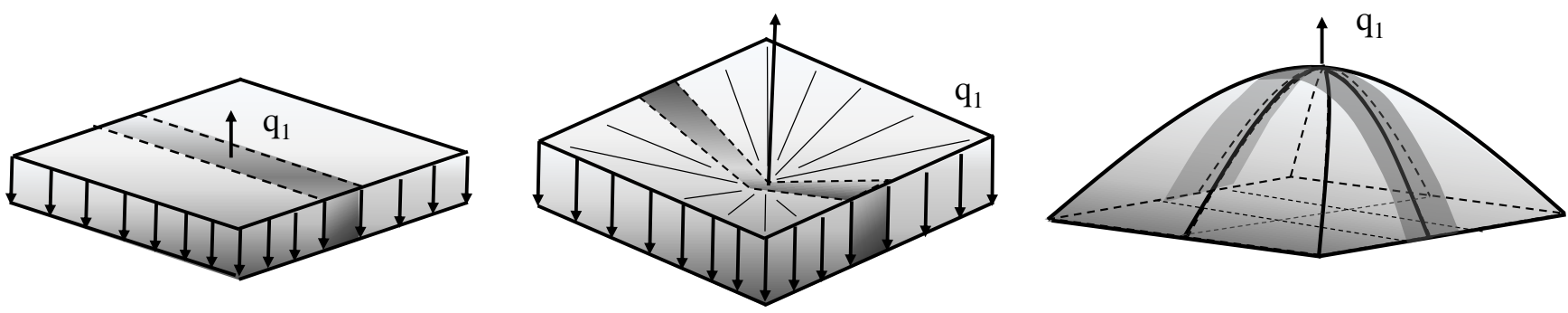

Figure 12. Stress distribution on the GSY above the cavity in 3D (a) uniform distribution, (b) Inverted triangular and (c) parabolic distribution.
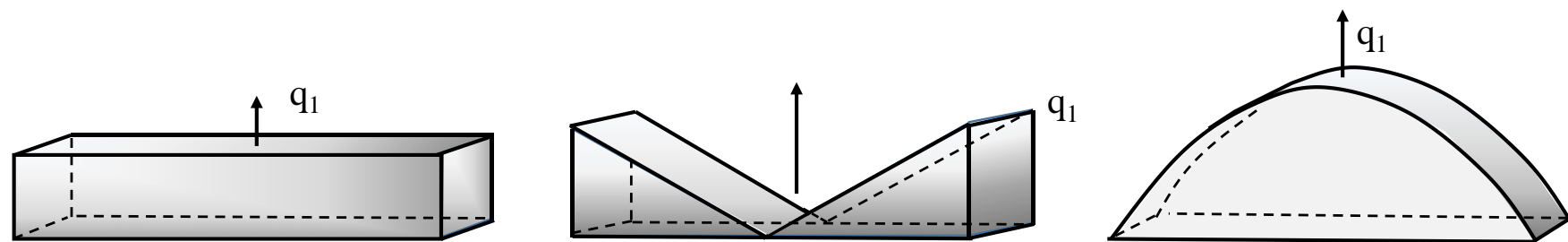

Figure 13. Stress distribution on the GSY above the cavity in 2D (a) uniform distribution, (b) Inverted triangular (c) parabolic distribution. 


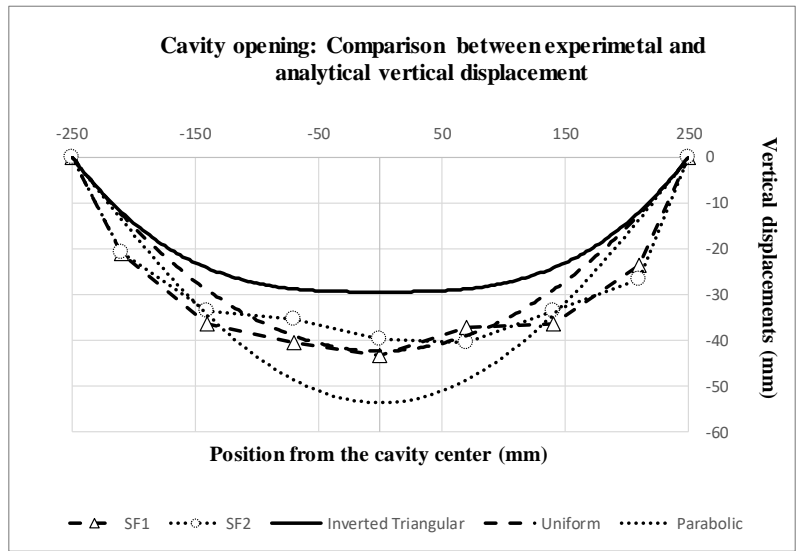

Figure 14. Comparison of experimental and analytical GSY vertical displacements after cavity opening - granular soil (SF1 and SF2)

5

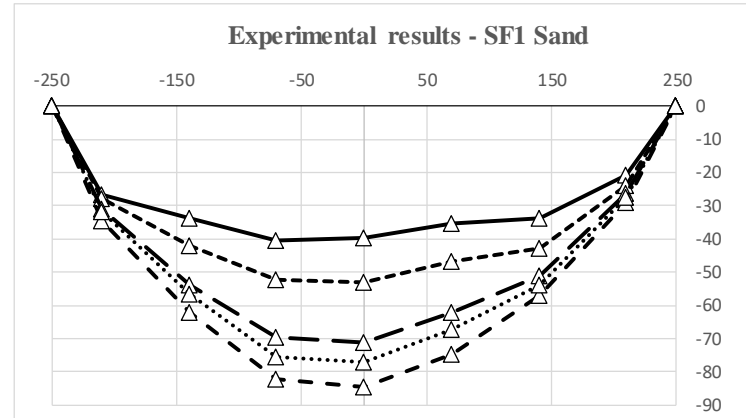

Position from the cavity center $(\mathbf{m m})$

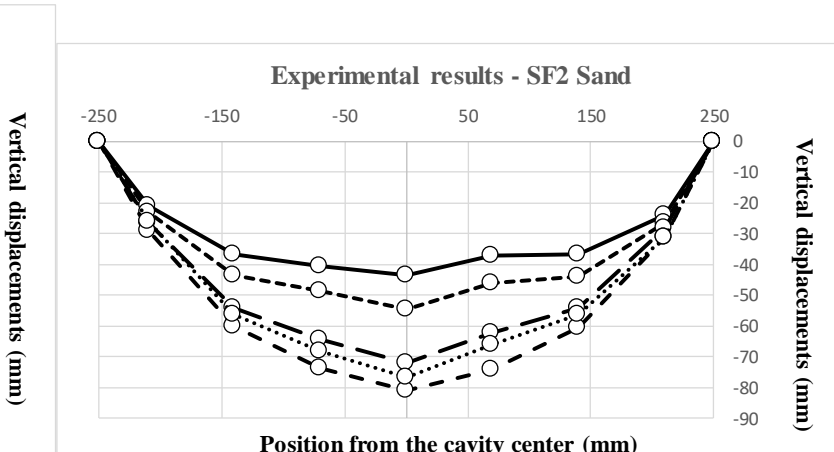

$\longrightarrow$ Cavity $-\infty-$ - Load-150N $\longrightarrow$ - Load-350N -0 Load-550N …

Figure 15. Evolution of the GSY displacements during loading and unloading for SF1 and SF2 


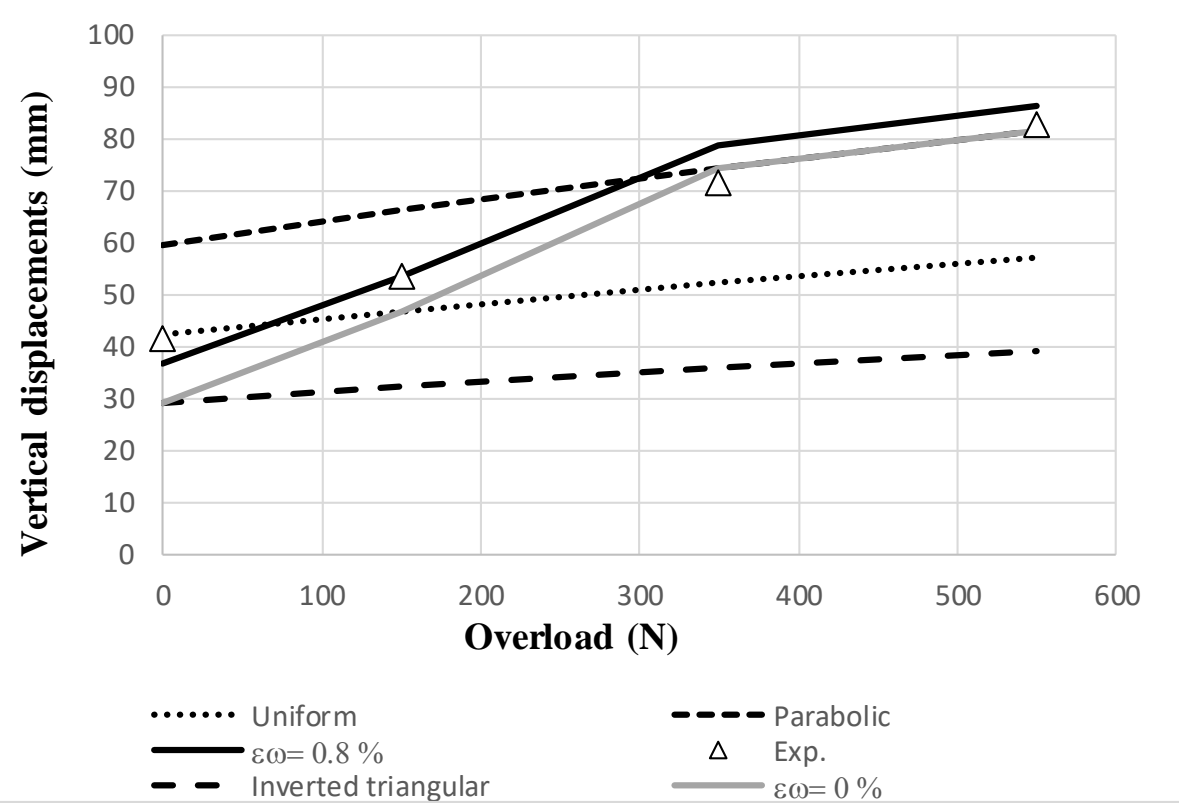

Figure 16. Evolution of the deflexion, comparison between analytical and experimental results 

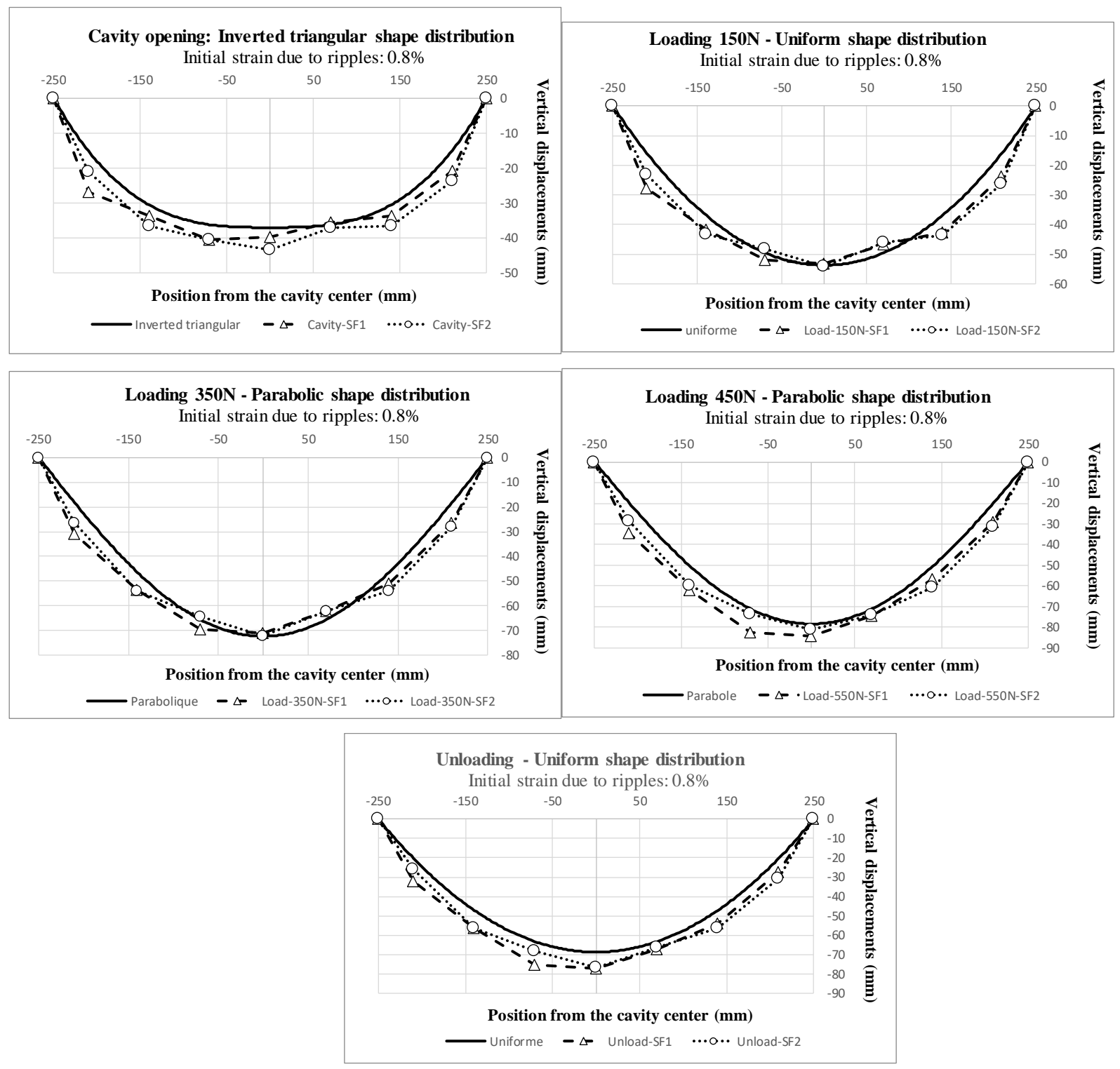

Figure 17. Vertical GSY displacement comparisons between experimental and analytical results
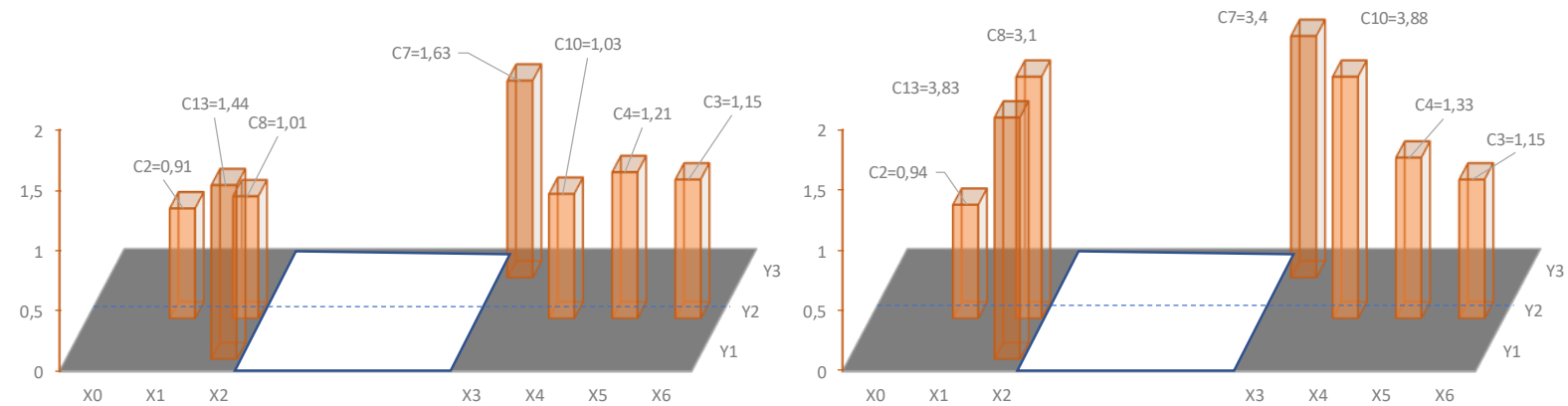

Figure 18. a) Ratio of initial stress, and b) final stress to $\gamma \mathrm{H}$ (with $\gamma$ : the density of the soil and H: the thickness of the soil layer) at the base of the soil layer for cohesive soil (Sand-kaolin, SK1) 


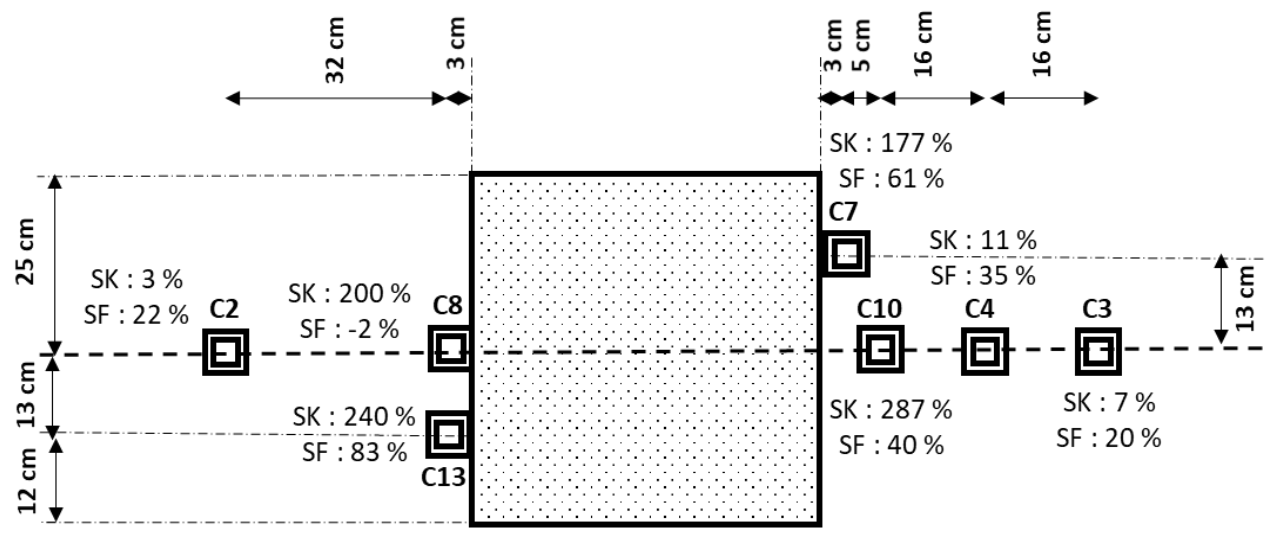

Figure 19. Comparison of load transfer in cases of granular soil (average of SF1 and SF2) and cohesive soils (average SK1 and SK2).

5
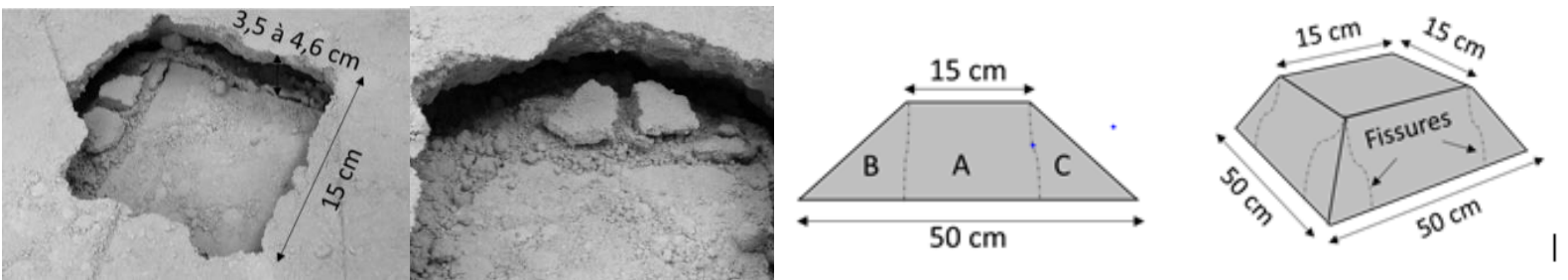

A

B

Figure 20. (A) Collapsed zones of the cohesive soil layer following a surface loading and (B) Geometry of the collapsed block for cohesive soil (Al Heib et al. 2020). 

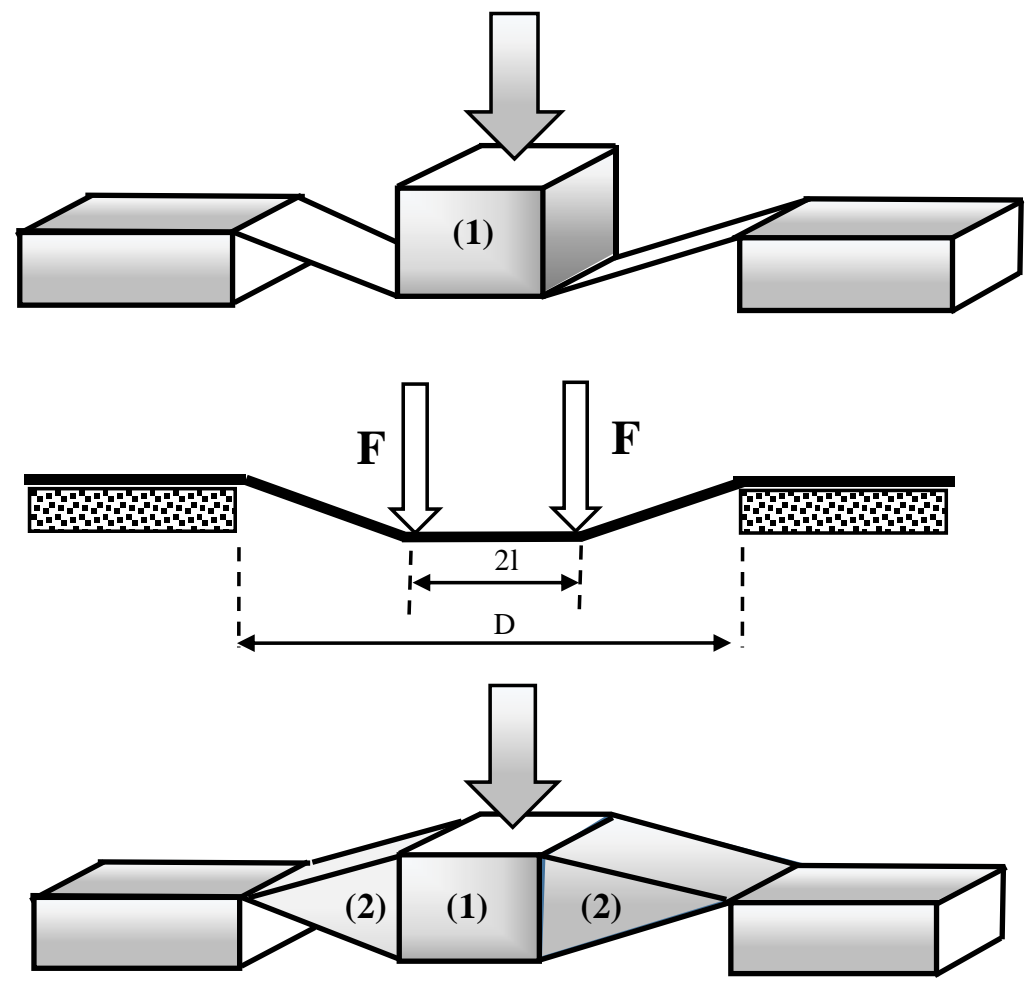

Figure 21. Considered geometries of the soil blocks included in the assessment of force $F$ in the analytical model: a) lower limit b) upper limit

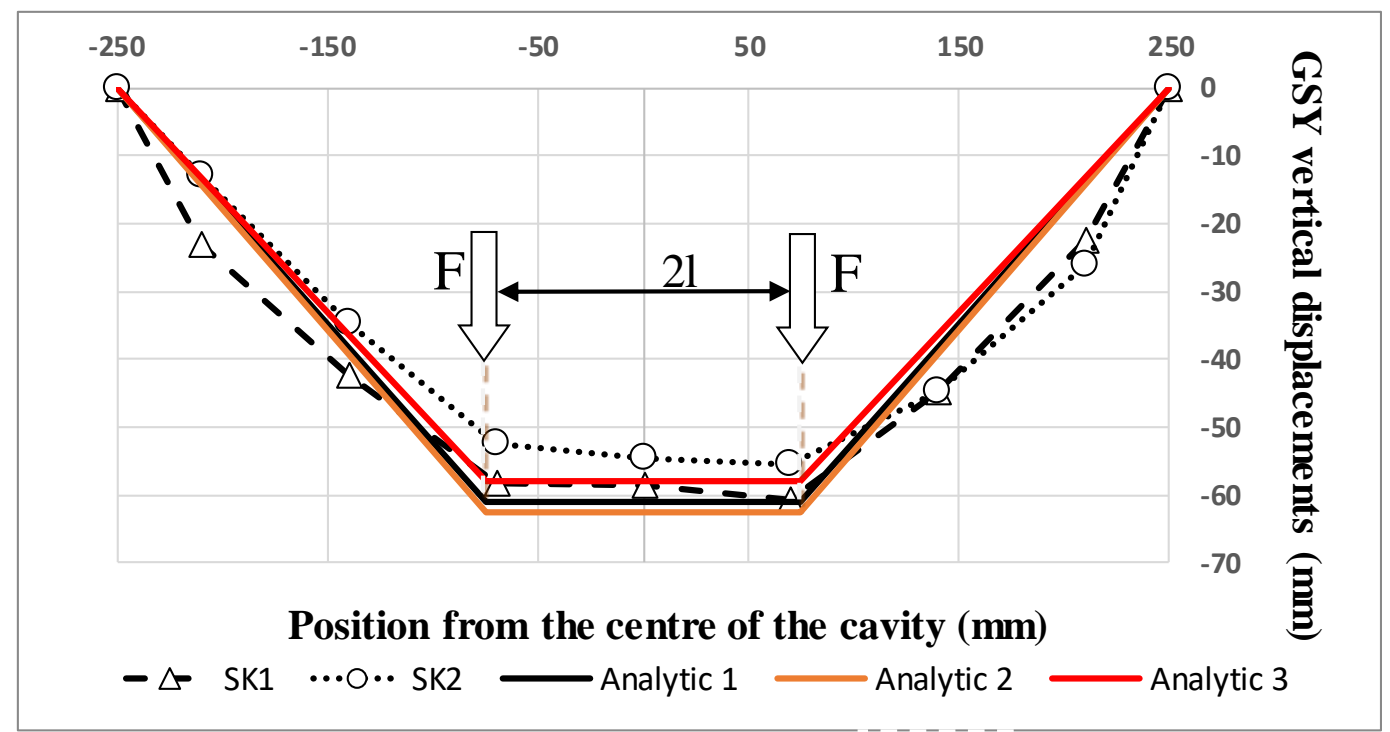

10 Figure 22. Comparison of the deflection of the GSY for SK1 and SK2 after failure (loading $=550 \mathrm{~N})$ with the analytical model 


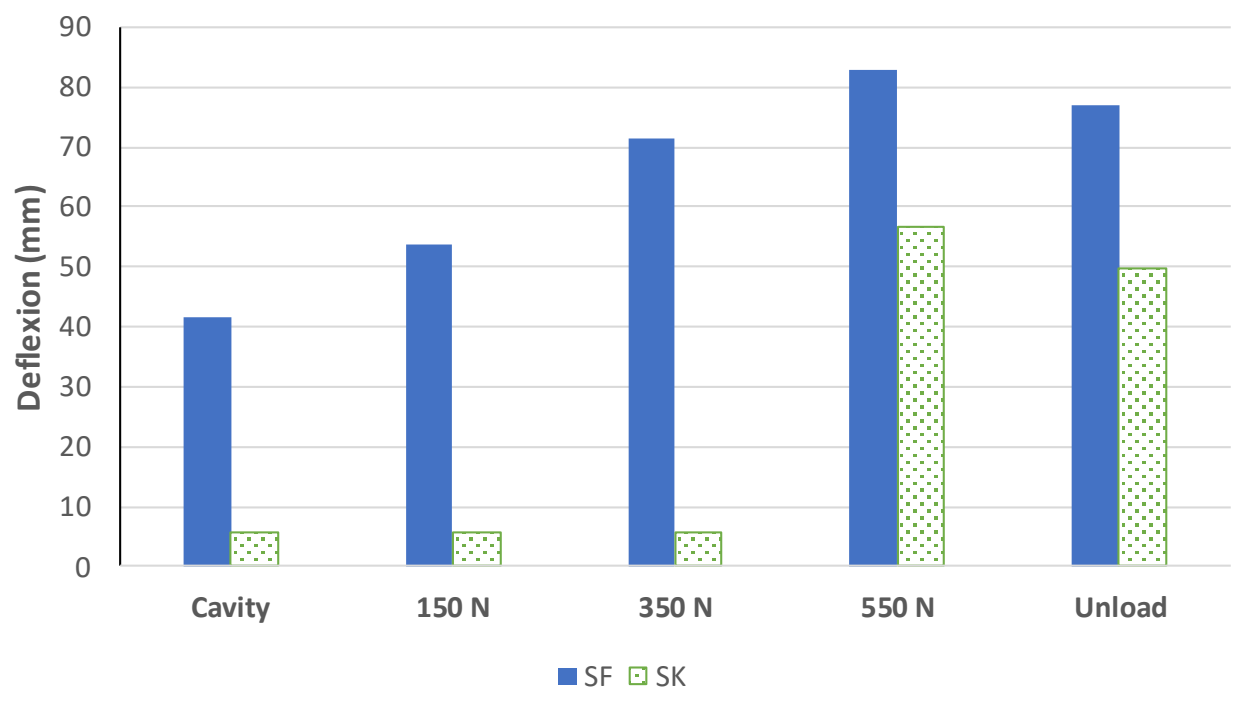

Figure 23. Comparison of the maximum deflection of the GSY for SF1 and SK1 during the different phases of the loading tests (Al Heib et al. 2020). 